\title{
Patterns of short-term sedimentation in a freshwater created marsh
}

\author{
Sarah K. Harter and William J. Mitsch \\ School of Natural Resources \\ The Ohio State University
}

\section{Introduction}

This study examines the short-term sedimentary processes occurring within the two one-hectare experimental wetland basins at the Olentagy River Wetland Research Park (ORWRP). The goals of this study were to determine the factors influencing the rate and patterns of sedimentation within this freshwater created wetland system, to evaluate the effectiveness of artificial soil horizon markers as a sedimentation measurement technique in freshwater wetllands, and to develop a dynamic sedimentation model to supplement field data. Field research for this project was conducted between July 1996 and July 1997. This paper represents the completion of the study that was first reported by Harter and Mitsch (1998).

\section{Methods}

Methods used in horizon marker installation, core retrieval, bulk density/organic matter content analysis, and total suspended solids/turbidity analysis have been previously described by Harter and Mitsch (1998) and Harter (1999).

A simple dynamic sedimentation model was developed to identify the important pathways of sediment transport deposition in the experimental wetlands. The model was also used to predict sedimentation rates within the wetlands for comparison with the rates measured by the artificial horizon marker technique.

A conceptual diagram was first developed using energese to determine the important components and pathways within the system (Fig. 1). The computer model was then created using the dynamic modelling and simulation software package STELLA ${ }^{\mathrm{TM}}$ Version 5. A simulation period of 365 days from July 41996 to July 31997 was chosen for calibration and comparison with available site data. Simulations used a Runge-Kutta fourth-order integration technique with a time step of 0.5 days.

The model was developed to describe sediment dynamics within the two experimental wetland basins at the ORWRP. The model was combined with site data to predict the

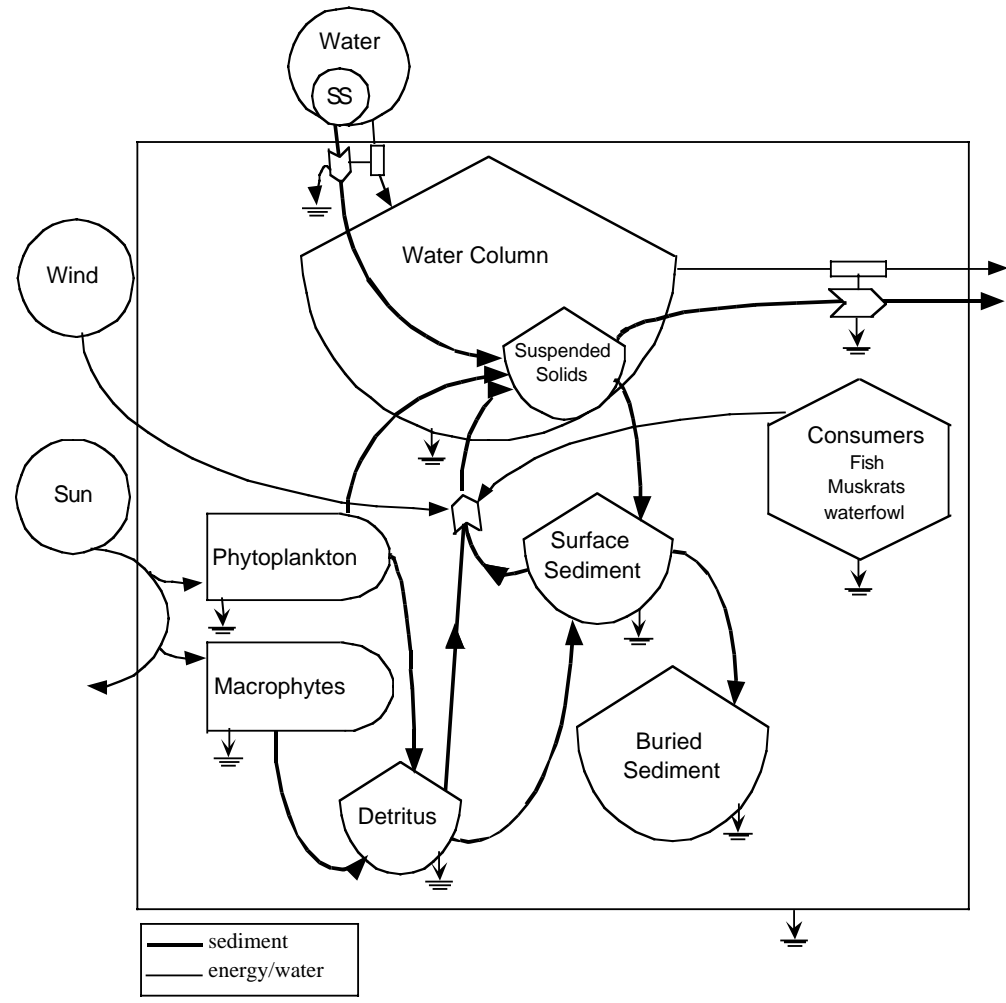

Figure1. Conceptual diagram of the sediment system in the experimental wetlands. 
sedimentary processes occurring within the wetlands and to determine the most important physical and biological factors influencing these processes. The model was composed of five submodels: hydrology, algal production, macrophyte production, detritus, and water column and surface sediments (Fig. 1). Differential equations for the model are given in Table1.

The hydrology submodel was constructed to provide a hydrologic budget for the wetland basins during the simulation time period. The submodel was based entirely on site data (Wang et al., 1997; 1998), and was not altered for any of the simulations. Factors included in the model were inflow pumped from the river, direct precipitation, evapotranspiration, surface outflow through the weir, and seepage to and from the groundwater (Table 1). During the simulation period water levels in both basins were lowest between April and June 1997 (Fig. 2). During this drawdown period, the water volume was reduced to nearly zero. Highest water levels generally occurred during the winter months, with the only exception occurring immediately after pumps were turned on following the spring drawdown. For the majority of the simulation period, the basin water volumes oscillated near $2500 \mathrm{~m}^{3}$ (Fig. 2).

Primary production was divided into two submodels consisting of the major biomass contributors: algae and macrophytes (Table 1). The primary forcing function influencing the growth of these two state variables was considered to be sunlight. Losses from the algal compartment came from settling out of the water column, and losses from the macrophyte biomass compartment resulted from senescence.

The detritus submodel was designed to represent the total detrital biomass pool within the system that could ultimately contribute autochthonous materials to the surface sediment. Inputs to the detritus biomass compartment came directly from the outputs of both the algae and macrophyte submodels (Table 1). Losses from the detritus compartment came from decay and sedimentation.

The sediment submodel contained both a suspended solids state variable and a surface sediment state variable (Table 1). The suspended solids compartment is located within the wetland water column and receives input from the inflow suspended solids and from resuspension of the surface sediments. Losses from the suspended solids compartment occur through sedimentation to the surface sediment and through surface outflow from the wetland. The surface sediment compartment receives input through sedimentation from the water column and through sedimentation of detrital biomass. For simplification of the system, it was assumed that no compaction or burial to deeper sediments occurred over the simulation time period.

The parameters and coefficients included in this model were either taken from literature or were based on calibration with site data (Table 2). The model was calibrated using a stepwise calibration procedure. The sediment submodel was linked to the hydrology submodel and calibrated based on inflow and outflow suspended solids concentrations that
Table 1. Differential equations used in the model.

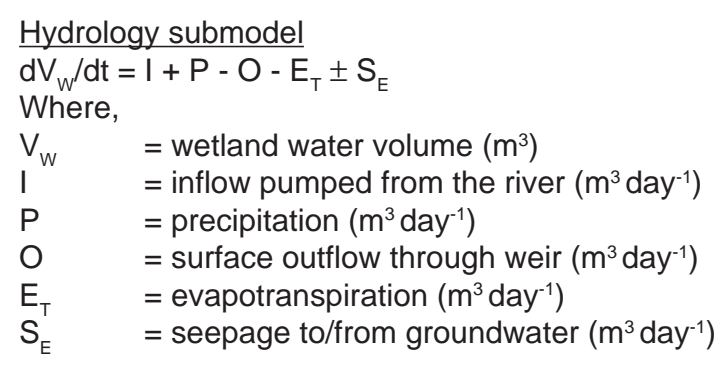

Primary productivity submodel

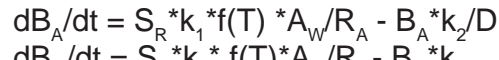

$\mathrm{dB}_{\mathrm{M}} / \mathrm{dt}=\mathrm{S}_{\mathrm{R}}{ }^{*} \mathrm{k}_{3}{ }^{*} \mathrm{f}(\mathrm{T})^{*} \mathrm{~A}_{\mathrm{M}} / \mathrm{R}_{\mathrm{M}}-\mathrm{B}_{\mathrm{M}}{ }^{*} \mathrm{k}_{4}$

Where,

$\mathrm{B}_{\mathrm{A}} \quad=$ algal biomass $(\mathrm{g})$

$\mathrm{B}_{\mathrm{M}} \quad=$ macrophyte biomass $(\mathrm{g})$

$\mathrm{S}_{\mathrm{R}} \quad=$ solar radiation $\left(\mathrm{kcal} \mathrm{m}^{-2}\right.$ day $\left.^{-1}\right)$

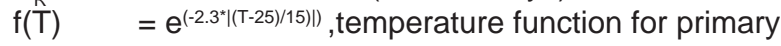

productivity

$\mathrm{T} \quad=$ water temperature $\left({ }^{\circ} \mathrm{C}\right)$

$A_{w} \quad=$ open water area $\left(\mathrm{m}^{2}\right)$

$A_{M} \quad=$ wetland area covered by macrophytes $\left(\mathrm{m}^{2}\right)$

$\mathrm{D}=\mathrm{V}_{\mathrm{W}} / \mathrm{A}$, average water depth $(\mathrm{m})$

$R_{A} \quad=$ algae energy to biomass ratio ( $\mathrm{kcal} \mathrm{g}^{-1}$ )

$\mathrm{R}_{\mathrm{M}} \quad=$ macrophyte energy to biomass ratio $\left(\mathrm{kcal} \mathrm{g}^{-1}\right)$

$\mathrm{k}_{1} \quad=$ phytoplankton solar efficiency

$\mathrm{k}_{2} \quad=$ algal settling rate $\left(\mathrm{m}_{\text {day }}{ }^{-1}\right)$

$\mathrm{k}_{3} \quad=$ macrophyte solar efficiency

$\mathrm{k}_{4}=$ macrophye death rate $\left(\right.$ day $\left.^{-1}\right)$

Detritus submodel

$\mathrm{dB}_{\mathrm{D}} / \mathrm{dt}=\mathrm{B}_{\mathrm{A}}{ }^{*} \mathrm{k}_{2} / \mathrm{D}+\mathrm{B}_{\mathrm{M}}{ }^{*} \mathrm{k}_{4}-\mathrm{B}_{\mathrm{D}}{ }^{*} \mathrm{k}_{5}{ }^{*} \mathrm{f}(\mathrm{T})_{2}-\mathrm{B}_{\mathrm{D}}{ }^{*} \mathrm{k}_{6}$

Where,

$\mathrm{B}_{\mathrm{D}} \quad=\operatorname{detritus}(\mathrm{g})$

$f(T)_{2}=1.06^{(T-20)}$, temperature function for decay

$\mathrm{k}_{5}=$ detritus decay rate $\left(\right.$ day $\left.^{-1}\right)$

$\mathrm{k}_{6}=$ detritus sedimentation rate $\left(\right.$ day $\left.^{-1}\right)$

Sediment submodel

$\mathrm{dS}_{\mathrm{S}} / \mathrm{dt}=\mathrm{S}_{1}{ }^{*} \mathrm{I}+\mathrm{k}_{7}{ }^{*} \mathrm{~A}^{*} \mathrm{f}(\mathrm{D})-\mathrm{S}_{\mathrm{S}}{ }^{*} \mathrm{k}_{8} / \mathrm{D}-\left(\mathrm{S}_{\mathrm{S}} / \mathrm{V}_{\mathrm{w}}\right)^{*} \mathrm{O}$

$\mathrm{dS}_{\mathrm{U}} / \mathrm{dt}=\mathrm{B}_{\mathrm{D}}{ }^{*} \mathrm{k}_{6}+\mathrm{S}_{\mathrm{S}}{ }^{*} \mathrm{k}_{8} / \mathrm{D}-\mathrm{k}_{7}{ }^{*} \mathrm{~A}^{*} \mathrm{f}(\mathrm{D})$

Where,

$\mathrm{S}_{\mathrm{S}} \quad=$ suspended solids mass $(\mathrm{g})$

$\mathrm{S}_{u} \quad=$ surface sediment mass $(\mathrm{g})$

$S_{1} \quad=$ inflow suspended solids concentration $\left(\mathrm{g} \mathrm{m}^{-3}\right)$

A $\quad=$ total wetland area $\left(\mathrm{m}^{2}\right)$

$f(D) \quad=0.25 /(D+0.25)$

$\mathrm{k}_{7}=$ resuspension rate $\left(\mathrm{g} \mathrm{m}^{-2}\right.$ day-1) $\left.^{-1}\right)$

$\mathrm{k}_{8} \quad=$ sediment falling velocity $\left(\mathrm{m}^{-1 a y^{-1}}\right)$

were measured daily during the simulation time period. The primary productivity submodel was calibrated using site algal peak biomass data from 1994 and macrophyte peak biomass data from 1997 (Wu and Mitsch, 1995; Mitsch and Bouchard, 1998). The detritus submodel was calibrated with the sediment submodel to contribute $10 \%$ organic matter to the total surface sediment load based on organic matter content data collected from basin sediments in 1997. 
a)

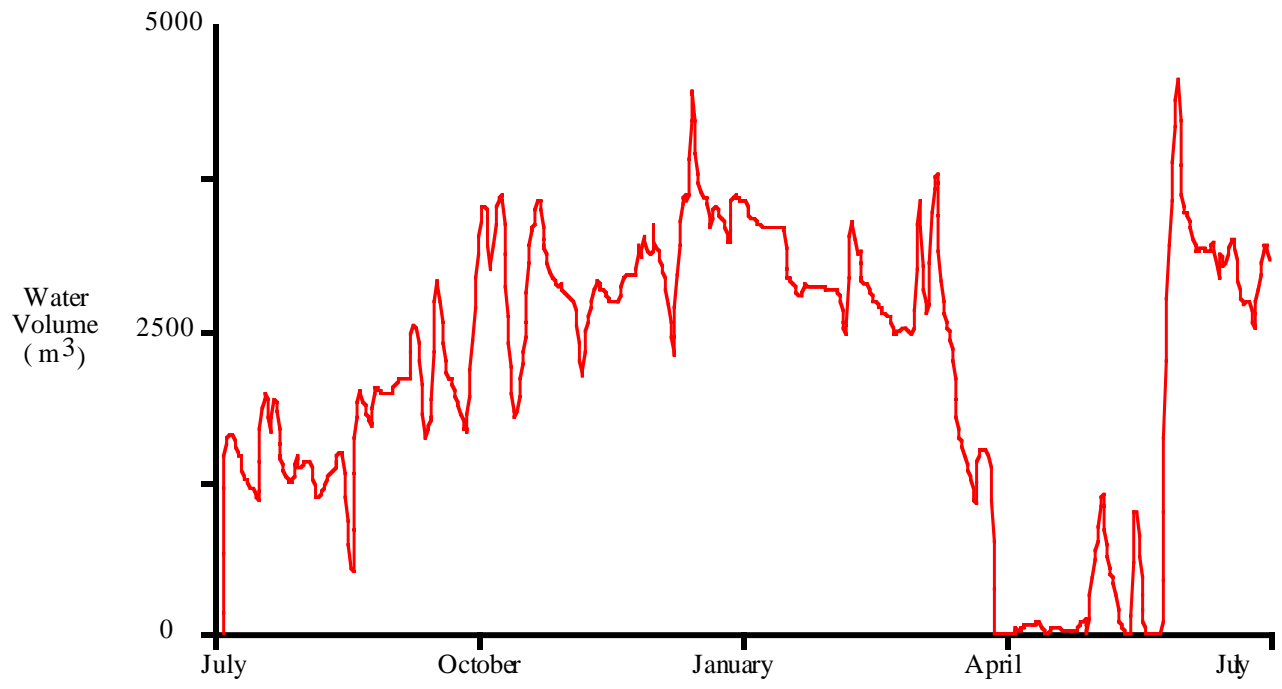

b)

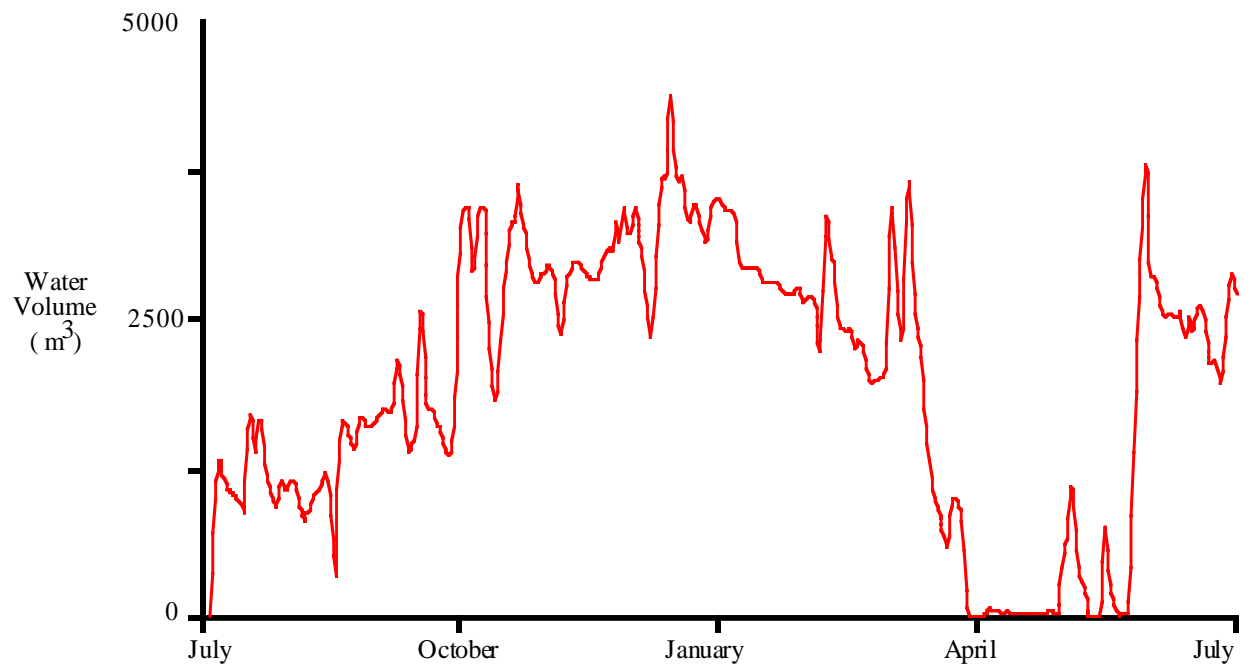

Figure 2. Observed water volume for a) Wetland 1 and b) Wetland 2 from July 1996-July 1997 as determined by site hydrologic data.

Model simulations were conducted to explain the relative importance of the physical and biological factors affecting sedimentation and sediment retention within the wetland and to predict the average sedimentation rate for the wetlands over the simulation time period. Parameters that were altered during the simulations included the sediment settling velocity, the detrital sedimentation rate, and the sediment resuspension rate (Table 2).

\section{Results}

Results of the bulk density/organic matter content analysis and total suspended solids/turbidity analysis are summarized in Harter and Mitsch (1998).

\section{Sediment Mass Accumulation Rates}

Because bulk density measurements were relatively constant throughout the two wetlands, the sediment mass accumulation rates showed patterns similar to the sediment accretion rates $\left(\mathrm{cm} \mathrm{yr}^{-1}\right)$ (see Harter and Mitsch [1998] for accretion rate summary). Average accumulation rates varied between 12.4 and $69.7 \mathrm{~kg}$ dry wt m $\mathrm{m}^{-2} \mathrm{yr}^{-1}$ for Wetland 1 and between 13.2 and $65.0 \mathrm{~kg} \mathrm{~m}^{-2} \mathrm{yr}^{-1}$ for Wetland 2 (Table 3). For Wetland 1, sand-measured average accumulation rates were significantly higher than both feldspar and glittermeasured rates, but no significant differences between marker types were found in Wetland 2 (one-way ANOVA, Tukey's pairwise comparison; $p<0.05$ ) (Fig. 3). Significant differences between marker types were detected within only five of the 27 plots in which more than one marker type was recovered (one-way ANOVA; p < 0.05) (Table 3). Average accumulation rates for Wetland 1 and Wetland 2 were 35.7 and $36.7 \mathrm{~kg} \mathrm{~m}^{-2} \mathrm{yr}^{-1}$, respectively. No significant difference was found in accumulation rates between the two basins (two-sided t-test, $\mathrm{p}>0.05$ ).

As with accretion rates, mass accumulation rates were significantly higher in deepwater plots than in shallow plots for both Wetland 1 and Wetland 2 (one-sided t-test, p < 0.05 ) (Fig. 4). Average accumulation rates were 26.5 and $39.8 \mathrm{~kg} \mathrm{~m}^{-2} \mathrm{yr}^{-1}$ for the shallow and deep plots in Wetland 1 , 
Table 2. Model parameters, definitions, values, and sources.

\begin{tabular}{|c|c|c|c|}
\hline Symbol & Name & Value & Source \\
\hline \multicolumn{4}{|c|}{ Parameters and Coefficients } \\
\hline $\mathrm{k}_{1}$ & phytoplankton solar efficiency & 0.005 & \multirow{5}{*}{$\begin{array}{l}\text { Mitsch and Reeder, } 1991 \\
\text { calibration } \\
\text { calibration }\end{array}$} \\
\hline$k_{2}$ & phytoplankton settling rate & $0.005 \mathrm{~m} \mathrm{day}^{-1}$ & \\
\hline $\mathrm{k}_{3}^{2}$ & macrophyte solar efficiency & 0.005 & \\
\hline \multirow[t]{2}{*}{$\mathrm{k}_{4}^{3}$} & macrophyte death rate $300<\mathrm{t}<100$ & & \\
\hline & $300>t>100$ & 0.07 & \\
\hline $\mathrm{k}_{5}$ & detritus decay rate & 0.005 day $^{-1}$ & \multirow{5}{*}{$\begin{array}{l}\text { Mitsch and Gosselink, } 1993 \\
\text { calibration } \\
\text { calibration } \\
\text { calibration }\end{array}$} \\
\hline $\mathrm{k}_{6}$ & detritus sedimentation rate & 0.001 day $^{-1}$ & \\
\hline $\mathrm{k}_{7}^{6}$ & resuspension rate & $5 \mathrm{~g} \mathrm{~m}^{-2}$ day $^{-1}$ & \\
\hline $\mathrm{k}_{8}$ & sediment settling velocity $270<t<150$ & $0.4 \mathrm{~m} \mathrm{day}^{-1}$ & \\
\hline & $270>t>150$ & 0.1 & \\
\hline \multirow[t]{2}{*}{$A_{w}$} & area of basin with open water & $3254 \mathrm{~m}^{2}(\mathrm{~W} 1)$ & \multirow[t]{2}{*}{ Bouchard et al.,1998 } \\
\hline & & $3002 \mathrm{~m}^{2}(\mathrm{~W} 2)$ & \\
\hline \multirow[t]{2}{*}{$A_{M}$} & basin area covered by macrophytes & $3857 \mathrm{~m}^{2}(\mathrm{~W} 1)$ & \multirow[t]{2}{*}{ Bouchard et al., 1998} \\
\hline & & $4141 \mathrm{~m}^{2}(\mathrm{~W} 2$ & \\
\hline \multirow{4}{*}{$\begin{array}{l}R_{A} \\
R_{M} \\
A\end{array}$} & algae energy/biomass ratio & $3.65 \mathrm{kcal} \mathrm{g}^{-1}$ & \multirow{4}{*}{$\begin{array}{l}\text { Jørgensen et al., } 1991 \\
\text { Jørgensen et al., } 1991 \\
\text { estimated from Bouchard } \\
\text { et al., } 1998\end{array}$} \\
\hline & phytoplankton energy /biomass ratio & $4.5 \mathrm{kcal} \mathrm{g}^{-1}$ & \\
\hline & area of the wetland basin & $7211 \mathrm{~m}^{2}(\mathrm{~W} 1)$ & \\
\hline & & $7228 \mathrm{~m}^{2}(\mathrm{~W} 2)$ & \\
\hline \multicolumn{4}{|c|}{ Forcing Functions } \\
\hline I & inflow pumped from the river & $\mathrm{m}^{3}$ day $^{-1}$ & \multirow{8}{*}{$\begin{array}{l}\text { Wang et al., 1997, } 1998 \\
\text { Wang et al., 1997, } 1998 \\
\text { Wang et al., 1997, } 1998 \\
\text { Wang et al., 1997, } 1998 \\
\text { Wang et al., 1997, } 1998 \\
\text { field data } \\
\text { field data } \\
\text { field data }\end{array}$} \\
\hline$P$ & precipitation & $\mathrm{m}^{3}$ day $^{-1}$ & \\
\hline O & surface outflow through weir & $\mathrm{m}^{3}$ day $^{-1}$ & \\
\hline $\mathrm{E}_{\mathrm{T}}$ & evapotranspiration & $\mathrm{m}^{3}$ day $^{-1}$ & \\
\hline$S_{E}$ & seepage to/from groundwater & $\mathrm{m}^{3}$ day $^{-1}$ & \\
\hline$S_{R}^{E}$ & solar radiation & $\mathrm{kcal} \mathrm{m}^{-2} \mathrm{day}^{-1}$ & \\
\hline$T^{\mathrm{n}}$ & water temperature & ${ }^{\circ} \mathrm{C}$ & \\
\hline$S_{1}$ & inflow suspended solids concentration & $\mathrm{g} \mathrm{m}^{-3}$ & \\
\hline State Variables & \multicolumn{3}{|l|}{ Initial Value } \\
\hline $\mathrm{V}_{\mathrm{w}}$ & water volume in wetland & $0 \mathrm{~m}^{3}$ & \multirow{9}{*}{$\begin{array}{l}\text { estimated from Wu and } \\
\text { Mitsch, } 1995 \\
\text { estimated from Mitsch } \\
\text { and Bouchard, } 1998 \\
\text { estimated from } \\
\text { Findlay et al., } 1990\end{array}$} \\
\hline \multirow[t]{2}{*}{$\mathrm{B}_{\mathrm{A}}^{\mathrm{W}}$} & \multirow[t]{2}{*}{ algal biomass } & $700,000 \mathrm{~g}(\mathrm{~W} 1)$ & \\
\hline & & $700,000 \mathrm{~g}$ (W2) & \\
\hline \multirow[t]{2}{*}{$B_{M}$} & \multirow[t]{2}{*}{ macrophyte biomass } & $952,453 \mathrm{~g}(\mathrm{~W} 1)$ & \\
\hline & & $843,000 \mathrm{~g}(\mathrm{~W} 2)$ & \\
\hline \multirow[t]{2}{*}{$B_{D}$} & \multirow[t]{2}{*}{ detritus } & $1,101,635 \mathrm{~g}(\mathrm{~W} 1)$ & \\
\hline & & $1,033,810 \mathrm{~g}(\mathrm{~W} 2)$ & \\
\hline $\mathrm{S}_{\mathrm{S}}$ & suspended solids & $0 \mathrm{~g}$ & \\
\hline$S_{u}$ & surface sediments & $0 \mathrm{~g}$ & \\
\hline
\end{tabular}

and 32.4 and $40.9 \mathrm{~kg} \mathrm{~m}^{-2} \mathrm{yr}^{-1}$ for the shallow and deep plots in Wetland 2. Mass accumulation rates decreased with increasing distance from the inflow for both shallow and deepwater plots in Wetland 1 (Fig. 5). However, the trend was almost opposite in Wetland 2 as the deepwater accumulation rate dropped sharply near the inflow and then steadily increased to the outflow (Fig. 6).

\section{Estimation of Wetland Sediment Flux}

Summary data used to calculate the wetland sediment flux are given in Table 4. The hydrologic load for both wetlands was similar, with inflow approximately $1000 \mathrm{~m}^{3}$ day $^{-1}$ and outflow approximately $700 \mathrm{~m}^{3}$ day $^{-1}$ for both basins during the study period. Flow-weighted average turbidity for both wetlands was 34 NTU in the inflow and approximately $30 \mathrm{NTU}$ in the outflow. Conversion of turbidity to total suspended solids using the Equation:

$$
\mathrm{y}=1.24 * \mathrm{x}^{0.590}
$$

resulted in flow-weighted average TSS concentrations of $47 \mathrm{~g} \mathrm{~m}^{-3}$ in the inflow and approximately $37 \mathrm{~g} \mathrm{~m}^{-3}$ in the outflow of both wetlands. All data used in the sediment flux calculations are listed in Appendices A and B.

Estimates of wetland sediment flux based on the TSS/ turbidity relationship and daily turbidity and flow data were much lower than those suggested by core samples. The total inflow sediment load was calculated as $2332 \mathrm{~g} \mathrm{~m}^{-2} \mathrm{yr}^{-1}$ for Wetland 1 and $2372 \mathrm{~g} \mathrm{~m}^{-2} \mathrm{yr}^{-1}$ for Wetland 2 (Table 5). For Wetland 1, $950 \mathrm{~g} \mathrm{~m}^{-2} \mathrm{yr}^{-1}$ of sediment were retained, 
Table 3. Summary of sediment accumulation rates $\left(\mathrm{kg} \mathrm{m}^{-2}\right.$ $\left.\mathrm{yr}^{-1}\right) \pm$ standard error for each marker plot. $\mathrm{g}=$ glitter, $\mathrm{s}=$ sand, $\mathrm{f}=$ feldspar, and $\mathrm{c}=$ clay. "-" indicates that no visible marker was retrieved. Numbers in parentheses are sample sizes.

\begin{tabular}{|c|c|c|c|}
\hline Plot & Marker Type & Wetland 1 & Wetland 2 \\
\hline \multirow[t]{4}{*}{1} & $g$ & - & $58.0 \pm 9.9(2)$ \\
\hline & s & $69.7 \pm 10.6(4)$ & $65.0 \pm 10.6(2)$ \\
\hline & $f$ & - & - \\
\hline & c & - & - \\
\hline \multirow[t]{4}{*}{2} & g & $53.7 \pm 3.3^{a}(2)$ & $47.5 \pm 7.7(2)$ \\
\hline & $\mathrm{s}$ & $68.6 \pm 1.8^{\mathrm{b}}(2)$ & - \\
\hline & $f$ & - & - \\
\hline & c & - & - \\
\hline \multirow[t]{3}{*}{3} & g & $33.5 \pm 5.3(3)$ & $23.2 \pm 4.1$ (3) \\
\hline & s & $44.2 \pm 9.5(3)$ & $30.9 \pm 4.6(3)$ \\
\hline & $f$ & - & $20.0 \pm 4.4(3)$ \\
\hline \multirow[t]{4}{*}{4} & g & $24.6 \pm 4.2(3)$ & $32.6 \pm 6.4(2)$ \\
\hline & s & $49.3 \pm 17.5(2)$ & - \\
\hline & $f$ & - & - \\
\hline & c & - & - \\
\hline \multirow[t]{4}{*}{5} & g & $22.6 \pm 2.4^{\mathrm{a}}(2)$ & $41.6 \pm 6.6(3)$ \\
\hline & s & $34.5 \pm 3.8^{b}(2)$ & $39.8 \pm 7.3(2)$ \\
\hline & $f$ & $43.8 \pm 4.7^{\mathrm{c}}(2)$ & $43.4 \pm 9.5(2)$ \\
\hline & c & - & - \\
\hline \multirow[t]{4}{*}{6} & g & $42.0 \pm 8.8(2)$ & $27.7 \pm 3.1$ (2) \\
\hline & $\mathrm{s}$ & $49.3 \pm 9.5(2)$ & $33.5 \pm 6.6(3)$ \\
\hline & $f$ & - & - \\
\hline & c & - & - \\
\hline \multirow[t]{4}{*}{7} & $g$ & $43.1 \pm 8.8(2)$ & $41.2 \pm 4.0^{\mathrm{a}}(2)$ \\
\hline & $\mathrm{s}$ & $52.6 \pm 10.2(2)$ & - \\
\hline & $f$ & - & $20.1 \pm 0.4^{b}(2)$ \\
\hline & c & - & - \\
\hline \multirow[t]{4}{*}{8} & g & $26.1 \pm 3.1(2)$ & $38.0 \pm 9.1(2)$ \\
\hline & $\mathrm{s}$ & $24.8 \pm 3.1(2)$ & $35.7 \pm 7.7(2)$ \\
\hline & $f$ & - & $17.3 \pm 7.8$ (3) \\
\hline & c & - & - \\
\hline \multirow[t]{4}{*}{9} & $g$ & $30.0 \pm 3.3(2)$ & $57.3 \pm 6.2(3)$ \\
\hline & s & $34.7 \pm 5.9(2)$ & $48.5 \pm 6.2(2)$ \\
\hline & $f$ & - & - \\
\hline & c & - & - \\
\hline \multirow[t]{4}{*}{10} & g & $22.3 \pm 3.0(2)$ & $25.4 \pm 3.0(2)$ \\
\hline & $\mathrm{s}$ & $15.1 \pm 1.6(2)$ & $24.1 \pm 6.2(2)$ \\
\hline & $f$ & $15.7 \pm 5.8(2)$ & $27.4 \pm 3.5(2)$ \\
\hline & c & - & - \\
\hline \multirow[t]{4}{*}{11} & $g$ & $16.9 \pm 8.6(2)$ & $28.8 \pm 1.8(2)$ \\
\hline & s & $31.1 \pm 5.6(3)$ & $35.6 \pm 2.2(2)$ \\
\hline & $f$ & - & - \\
\hline & c & - & - \\
\hline \multirow[t]{4}{*}{12} & g & $41.2 \pm 7.3(2)$ & $46.0 \pm 1.8(3)$ \\
\hline & s & $51.8 \pm 11.3(2)$ & $39.4 \pm 4.4(2)$ \\
\hline & $f$ & $44.2 \pm 8.4(2)$ & - \\
\hline & c & - & - \\
\hline \multirow[t]{4}{*}{13} & g & - & $30.2 \pm 6.5(3)$ \\
\hline & $\mathrm{s}$ & - & $31.4 \pm 4.5(3)$ \\
\hline & $f$ & - & $23.8 \pm 3.3(2)$ \\
\hline & c & - & - \\
\hline \multirow[t]{4}{*}{14} & g & $21.8 \pm 7.7(2)$ & $23.5 \pm 5.7(3)$ \\
\hline & s & - & $13.2 \pm 3.4(2)$ \\
\hline & $f$ & - & - \\
\hline & c & - & - \\
\hline \multirow[t]{4}{*}{15} & g & $30.8 \pm 2.4^{a}(2)$ & $29.0 \pm 2.6^{a}(2)$ \\
\hline & s & $23.6 \pm 4.5^{a, b}(2)$ & $54.0 \pm 2.2^{\mathrm{b}}(2)$ \\
\hline & $f$ & $12.4 \pm 3.2^{b}(2)$ & $46.0 \pm 3.3^{\mathrm{b}}(2)$ \\
\hline & c & - & - \\
\hline 16 & $g$ & $21.4 \pm 2.4(2)$ & $63.5 \pm 3.3(3)$ \\
\hline & $\mathrm{s}$ & $33.4 \pm 7.6(3)$ & $58.0 \pm 5.5(3)$ \\
\hline & $f$ & $21.2 \pm 2.9(2)$ & $59.5 \pm 6.9(2)$ \\
\hline & c & - & - \\
\hline
\end{tabular}

equaling a retention of $40.7 \%$. Wetland 2 retained an estimated $1024 \mathrm{~g} \mathrm{~m}^{-2} \mathrm{yr}^{-1}$ of sediment, for a total retention of $43.1 \%$.

\section{Model}

\section{Primary Productivity}

Figure 7 depicts the results of the primary productivity simulation. Macrophyte biomass increased throughout the summer and peaked in early October 1996 near $600 \mathrm{~g} \mathrm{~m}^{-2}$ in Wetland 1 and $500 \mathrm{~g} \mathrm{~m}^{-2}$ in Wetland 2. Following the peak, macrophyte biomass rapidly decreased in both basins as a result of increased senescence from colder temperatures and less available sunlight. Simulated peak biomass values were comparable to those found by Mitsch and Bouchard (1998) for macrophyte productivity in 1997.

Algal biomass reached a peak value of approximately $200 \mathrm{~g} \mathrm{~m}^{-2}$ in both basins in July, followed by a more gradual decrease than that of macrophytes throughout the fall and winter (Fig. 7). This more gradual decrease stems from low settling rates of the dense algal mats in this system. Simulated peak biomass values for phytoplankton were similar to those found in the wetlands in 1994 (Wu and Mitsch,1995). Detritus

The model was calibrated so that $10 \%$ of the total surface sediment load would originate from the detrital biomass compartment. This percentage was chosen as an estimation to match the observed organic matter content of the basin sediments. To achieve the $10 \%$ detritus contribution a very low detritus sedimentation coefficient $\left(\mathrm{k}_{6}=0.001\right.$ day $\left.^{-1}\right)$ was used. Initial values of detritus biomass were estimated based on Findlay et al. (1990) who observed that detritus biomass of Typha spp. equaled approximately $67 \%$ of the live biomass present in a freshwater wetland during summer. The simulated detritus biomass increased slowly over the summer and then rapidly after the senescence of macrophytes in the fall (Fig. 7). Throughout the remainder of the year, detritus biomass decreased slowly to produce a small net accumulation of biomass within the system over the course of the simulation time period.

\section{Sediment}

Initial model runs assumed a constant sediment settling velocity $\left(\mathrm{k}_{8}=0.4\right)$ for the entire simulation period. However, results from this simulation did not agree with the observed pattern of sediment retention (Fig. 8). Use of a constant settling velocity underestimated the outflow suspended solids concentration from December to March, and resulted in an overall sediment retention of $63.2 \%$ in Wetland 1 and $68.6 \%$ in Wetland for the simulation period (Table 5).

Simulations which used a variable sediment settling velocity produced results more similar to the observed pattern of sedimentation. A reduction in the settling velocity during the winter $\left(\mathrm{k}_{8}=0.1\right)$ caused outflow suspended solids concentrations to more closely resemble the observed sediment outflow (Fig. 9). The overall sediment retention of $34.2 \%$ in Wetland 1 and $41.0 \%$ in Wetland 2 predicted by this simulation was also closer to the observed retention (Table 5). 


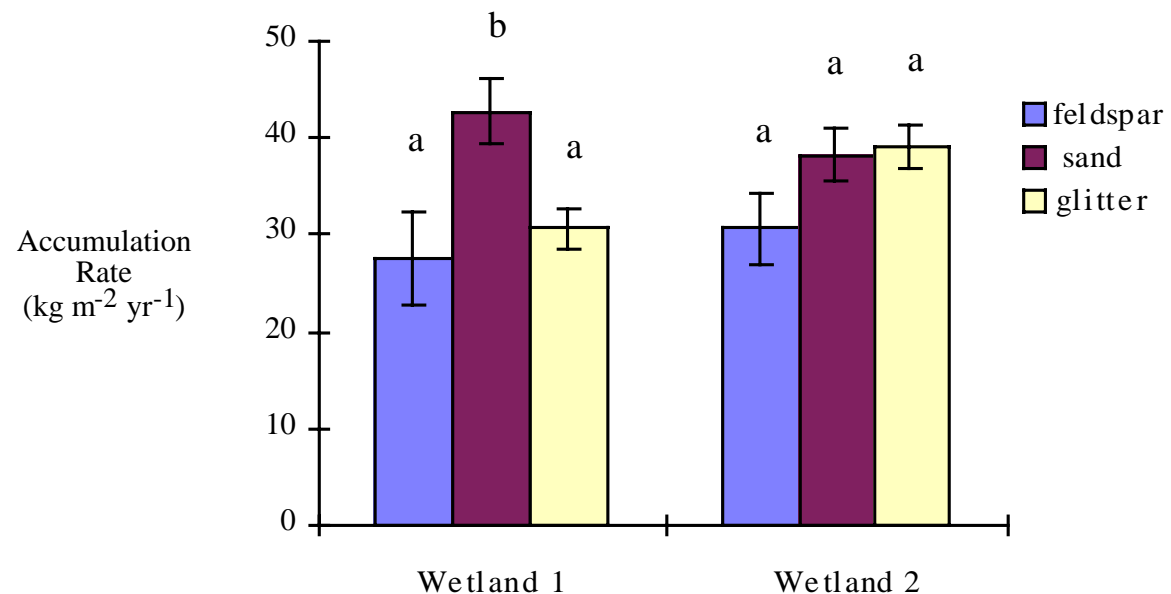

Figure 3. Comparison of average sediment accumulation rates $\left(\mathrm{kg} \mathrm{m}^{-2} \mathrm{yr}^{-1}\right)$ measured by the different marker materials for Wetland 1 and Wetland 2. Error bars indicate standard error. Differences in letters above the bars indicate significant differences between marker types within each wetland $(p<0.05)$.

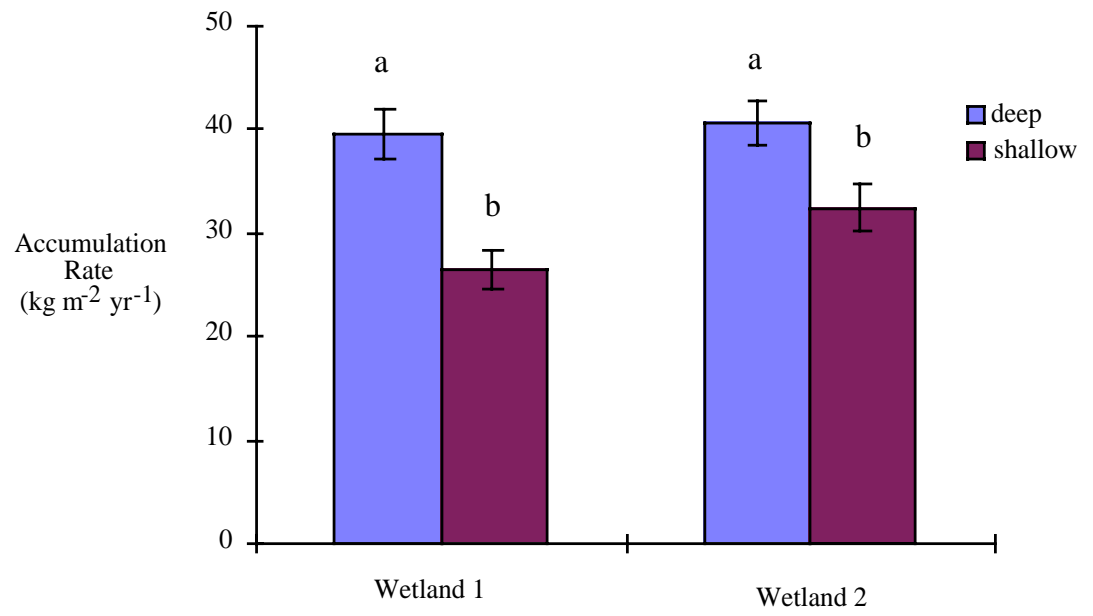

Figure 4. Comparison of average sediment accumulation rates $\left(\mathrm{kg} \mathrm{m}^{-2} \mathrm{yr}^{-1}\right)$ between deep and shallow plots for Wetland 1 and Wetland 2. Error bars indicate standard error. Differences in letters above the bars indicate significant differences between plots within each wetland $(p<0.05)$.

Table 4. Summary of data used to calculate sediment budget.

\begin{tabular}{|c|c|c|}
\hline & Wetland 1 & Wetland 2 \\
\hline \multicolumn{3}{|l|}{ Inflow } \\
\hline Flow $\left(m^{3}\right.$ day $\left.^{-1}\right)$ & $995 \pm 38(365)$ & $1014 \pm 38$ \\
\hline Turbidity (NTU) & $34 \pm 2(468)$ & $34 \pm 2(468)$ \\
\hline TSS $\left(\mathrm{g} \mathrm{m}^{-3}\right)^{\star}$ & $47 \pm 3(365)$ & $47 \pm 3(365)$ \\
\hline Total sed load $\left(\mathrm{g} \mathrm{m}^{-2} \mathrm{yr}^{-1}\right)$ & 2332 & 2372 \\
\hline \multicolumn{3}{|l|}{ Outflow } \\
\hline Flow $\left(m^{3}\right.$ day $\left.^{-1}\right)$ & $761 \pm 34(365)$ & $716 \pm 34(365)$ \\
\hline Turbidity (NTU) & $29 \pm 2(499)$ & $30 \pm 2(502)$ \\
\hline TSS $\left(\mathrm{g} \mathrm{m}^{-3}\right)^{*}$ & $35 \pm 2(365)$ & $38 \pm 2(365)$ \\
\hline Total sed load ( $\left.\mathrm{g} \mathrm{m}^{-2} \mathrm{yr}^{-1}\right)$ & 1382 & 1348 \\
\hline \multicolumn{3}{|l|}{ Retention } \\
\hline (\%) & 40.7 & 43.1 \\
\hline$\left(g^{-2} \mathrm{yr}^{-1}\right)$ & 950 & 1024 \\
\hline
\end{tabular}

Table 5. Comparison of sediment retention by Wetland 1 and Wetland 2 under observed and simulated conditions.

\begin{tabular}{|c|c|c|c|c|}
\hline \multirow[t]{2}{*}{ Simulation } & \multicolumn{2}{|c|}{$\begin{array}{c}\text { Sediment Load } \\
\left(\mathrm{g} \mathrm{m}^{-2} \mathrm{yr}^{-1}\right)\end{array}$} & \multicolumn{2}{|c|}{ Retention } \\
\hline & Inflow & Outflow & $\mathrm{g} \mathrm{m}^{-2} \mathrm{yr}^{-1}$ & $\%$ \\
\hline \multicolumn{5}{|l|}{ Wetland 1} \\
\hline 1- constant $\mathrm{k}_{8}$ & 2332 & 858 & 1474 & 63.2 \\
\hline 2- variable $\mathrm{k}_{8}^{\circ}$ & 2332 & 1534 & 798 & 34.2 \\
\hline 3- variable $k_{8}, 2 * k_{7}$ & 2332 & 1702 & 630 & 27.0 \\
\hline Observed & 2332 & 1382 & 950 & 40.7 \\
\hline \multicolumn{5}{|l|}{ Wetland 2} \\
\hline 1- constant $\mathrm{k}_{8}$ & 2372 & 745 & 1627 & 68.6 \\
\hline 2- variable $\mathrm{k}_{8}$ & 2372 & 1399 & 973 & 41.0 \\
\hline 3- variable $\mathrm{k}_{8}^{\circ}, 2{ }^{*} \mathrm{k}_{7}$ & 2372 & 1545 & 827 & 34.9 \\
\hline Observed & 2372 & 1348 & 1024 & 43.1 \\
\hline
\end{tabular}




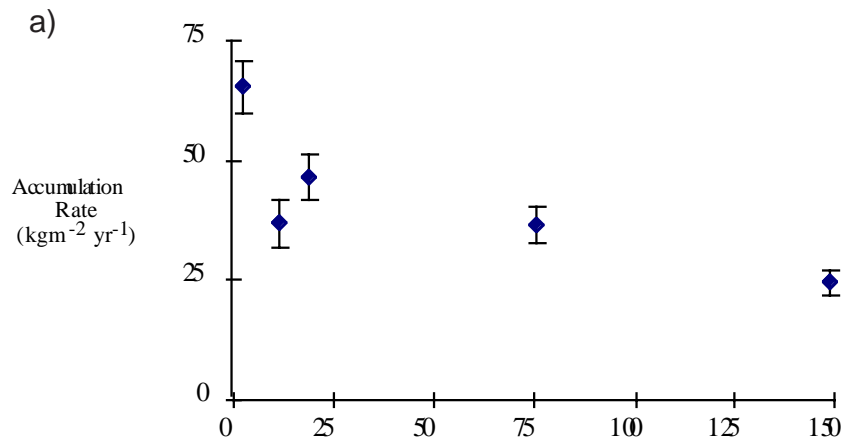

b)

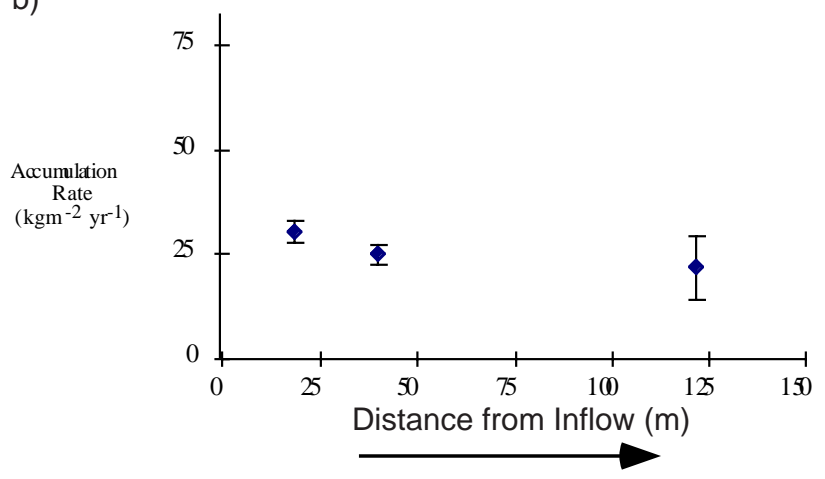

Figure 5. Average sediment accumulation rates $\left(\mathrm{kg} \mathrm{m}^{-2} \mathrm{yr}^{-1}\right)$ with increasing distance from the inflow for a) deep and b) shallow areas of Wetland 1. Error bars indicate standard error.

In order to simulate the effect of increased bioturbation in the wetland, such as might occur with increased carp or muskrat abundance, the model was run after doubling the surface sediment resuspension rate. An increase in the resuspension rate caused a $7.3 \%$ decrease in the overall sediment removal efficiency of Wetland 1 and a $6.1 \%$ decrease in Wetland 2 (Table 5). Figure 10 shows that this simulation overestimated sediment outflows during most of the year.

The model was also used to estimate the rate of sediment accumulation over the simulation time period. Under the simulation which used a variable settling (Simulation 2 on Table 5), the total sediment accumulation, including the $10 \%$ detritus input, resulted in an accumulation of $0.11 \mathrm{~cm}$ $\mathrm{yr}^{-1}$ in Wetland 1 and $0.13 \mathrm{~cm} \mathrm{yr}^{-1}$ in Wetland 2 at the end of the time period (Figure 11). Without the detrital input the model predicted a total sediment accumulation of approximately $0.09 \mathrm{~cm} \mathrm{yr}^{-1}$ in Wetland 1 and $0.11 \mathrm{~cm} \mathrm{yr}^{-1}$ in Wetland 2. Another simulation estimated sediment accumulation under the hypothetical situation where all of the biomass from primary producers went directly to surface sediments without decay or other losses. In this simulation the model predicted a total sediment accumulation of approximately $0.20 \mathrm{~cm} \mathrm{yr}^{-1}$ in Wetland 1 and $0.23 \mathrm{~cm} \mathrm{yr}^{-1}$ in Wetland 2 (Fig. 11).
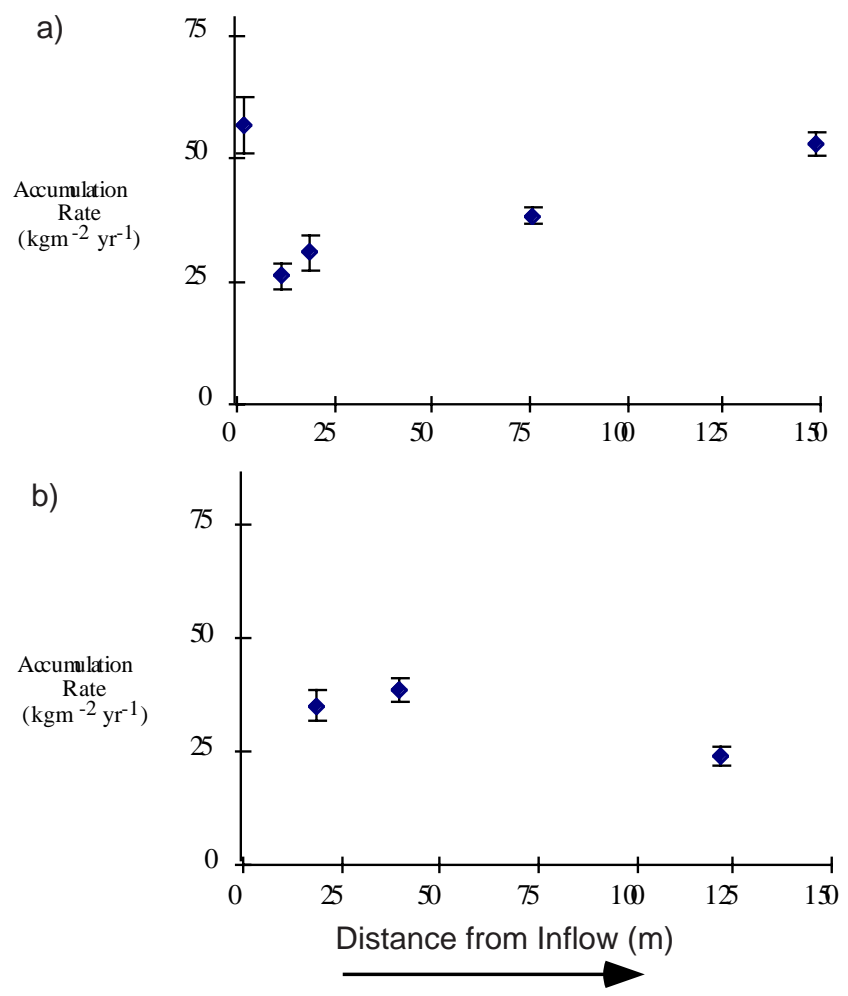

Figure 6. Average sediment accumulation rates $\left(\mathrm{kg} \mathrm{m}^{-2} \mathrm{yr}^{-1}\right)$ with increasing distance from the inflow for a) deep and b) shallow areas of Wetland 2. Error bars indicate standard error.

\section{Discussion}

\section{Effect of Distance from Inflow}

Most wetlands receiving surface inflow from adjacent rivers or tidal creeks display distinct spatial patterns of sedimentation because of the settling properties of suspended sediments. Greatest sediment accumulation usually occurs near the inflow source, with sedimentation rates decreasing rapidly with distance from the sediment source (French and Spencer, 1993; Brueske and Barrett, 1994; Cahoon, 1994; French et al., 1995; Reed et al., 1997). However, in the wetland system in this study, the spatial distribution of sedimentation was highly variable. Although Wetland 1 generally demonstrated the expected pattern of decreasing sedimentation rates with increasing distance from the inflow, results from Wetland 2 showed the opposite pattern. Sediment accumulation rates increased toward the outflow of Wetland 2 and were as high or higher than rates seen near the inflow. Fennessy et al. (1994) also observed spatial variability in sedimentation rates in a similar experimental wetland system and attributed erratic sediment distributions in that study to flow channelization. If the dominant factor affecting sedimentation in this system were its role as a low velocity environment compared to inflow water, then we would expect the spatial pattern seen in Wetland 1 to be more pronounced and we would also 
a)

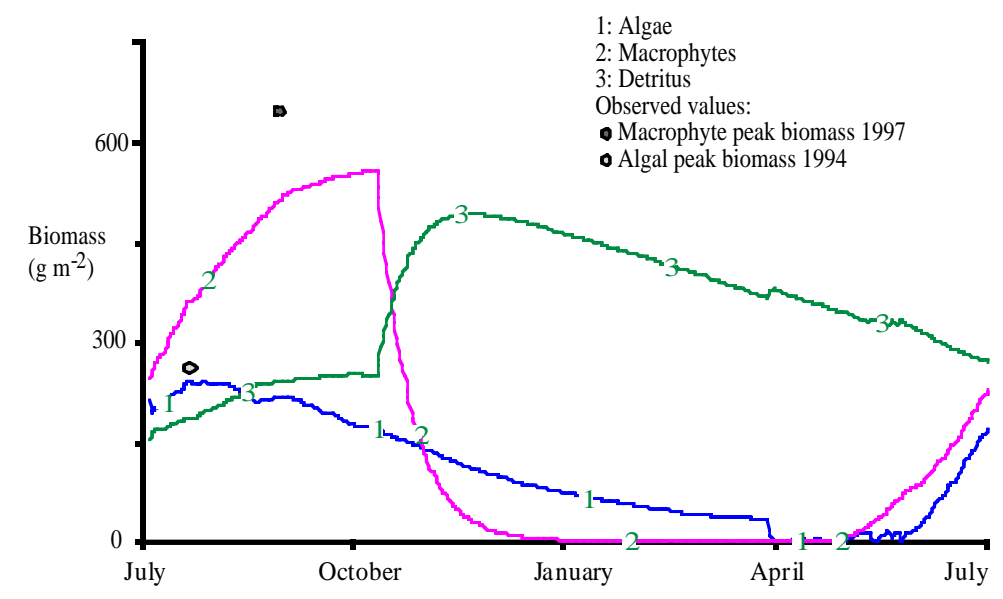

b)

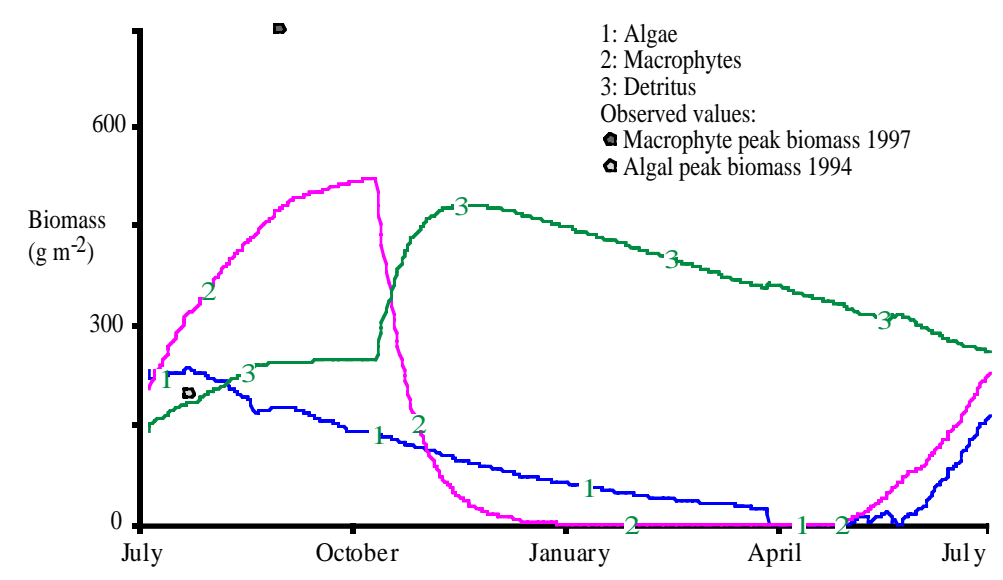

Figure 7. Simulated biomass production for a) Wetland 1 and b) Wetland 2 from July 1996-July 1997 for algae, macrophytes, and the total detrital pool. Observed values for macrophyte peak biomass in 1997 and algae peak biomass in 1994 are also indicated.

a)

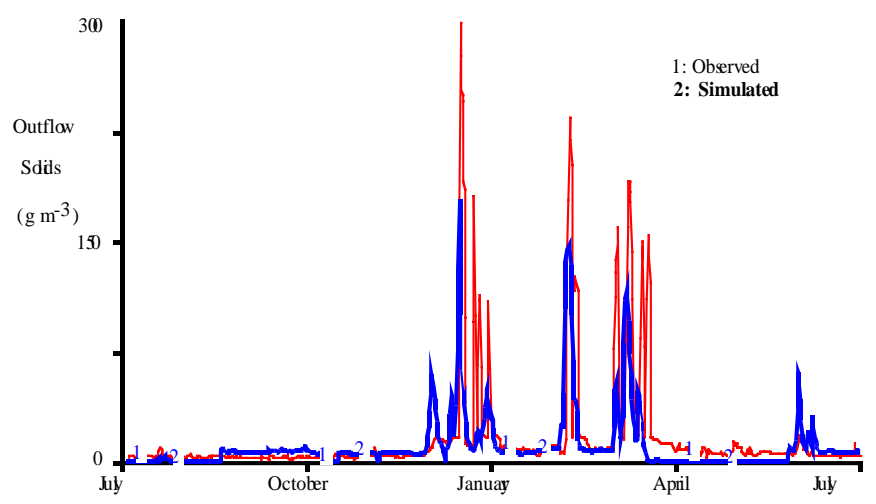

b)

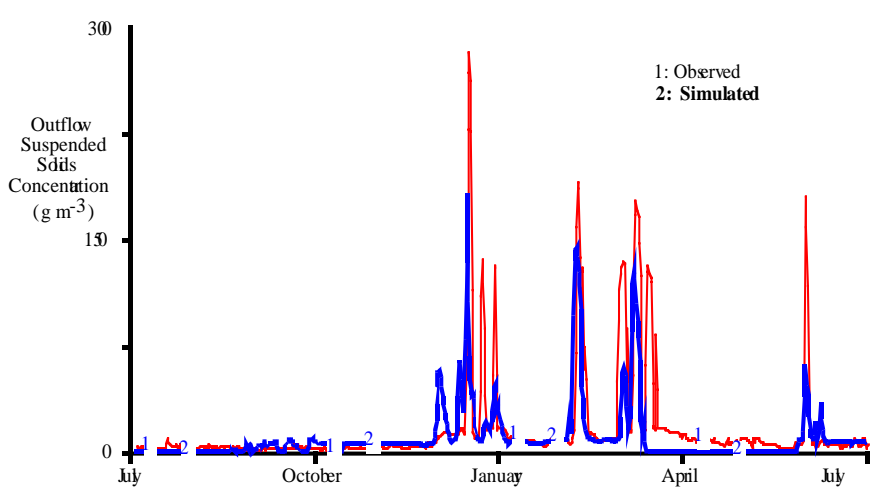

Figure 8. Comparison of observed outflow suspended solids concentrations with simulated outflow concentrations for a) Wetland 1 and b) Wetland 2 using a constant sedimentation coefficient. 
a)

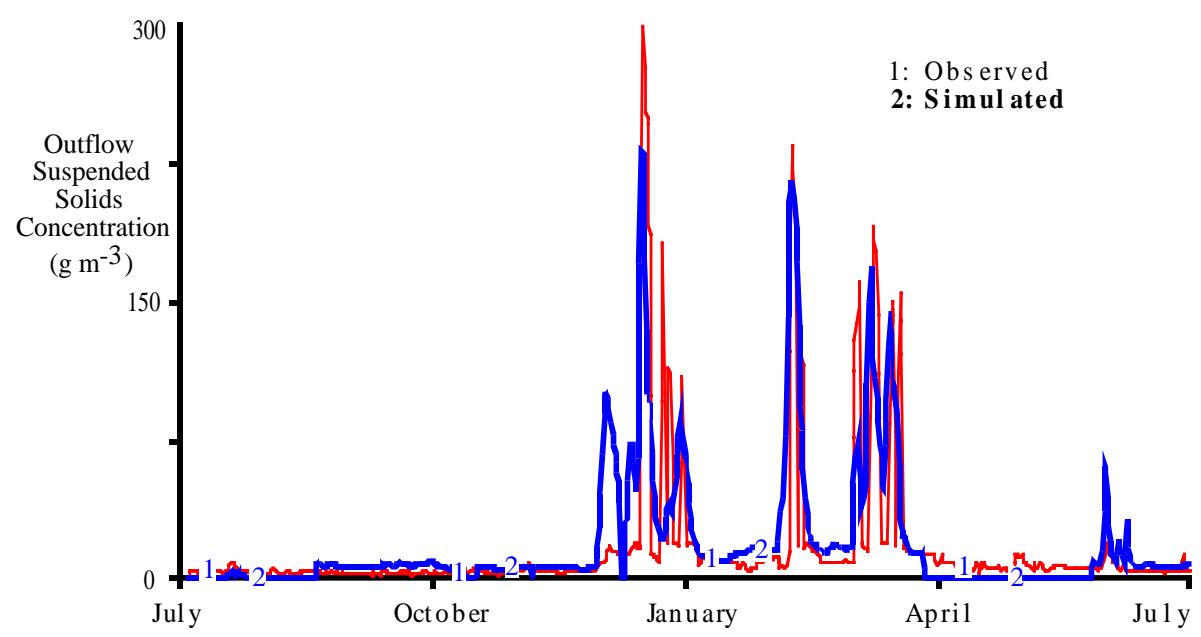

b)

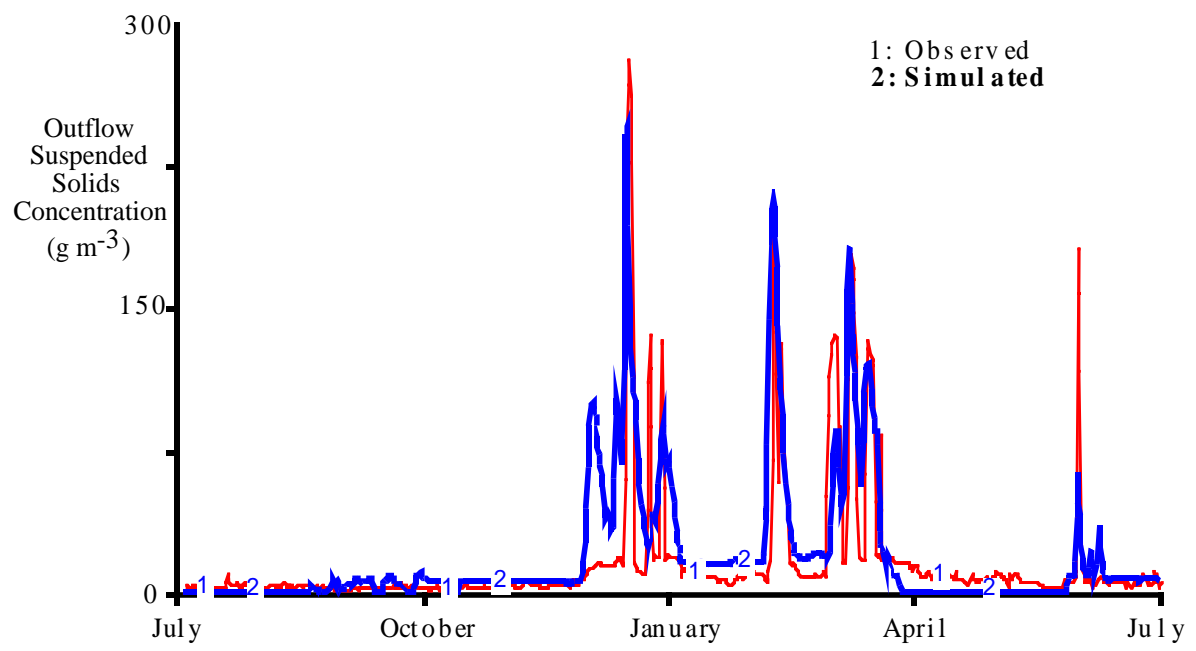

Figure 9. Comparison of observed outflow suspended solids concentrations with simulated outflow concentrations for a) Wetland 1 and $b$ ) Wetland 2 using a variable sediment settling velocity.

expect Wetland 2 to follow the same pattern as Wetland 1. The spatial variability in sedimentation between the two wetlands indicates that other factors are influencing sedimentation in this system. The variability between the two basins cannot be explained by differences in hydrology or vegetation, as both experienced the same hydrologic conditions during the study period and both had similar vegetative cover (Mitsch et al., 1998).

Bioturbation may have played a role in the spatial variability of sediment distribution. Benthic fish species, including carp, are known for causing sediment resuspension and for maintaining increased levels of turbidity in wetlands (Meijer et al., 1990; Wilcox and Hornbach, 1991; Breukelaar et al, 1994; Cline et al., 1994; Hanson and Butler, 1994). During the study period, both wetlands supported small populations (10-20 individuals) of large-sized common carp (personal observation) and also contained active muskrat huts (Svengsouk et al., 1997). Fish and wildlife abundance was similar for both wetlands during the study period (Cochran, 1998; Bouchard and Harter, 1998). During a drawdown at the end of the study period it was observed that one of the sedimentation plots in Wetland 1 was partially destroyed by a muskrat path that had been scoured into it, and carp in both basins were observed to stir the sediments while swimming during low flow periods. Metzger and Mitsch (1997) closely linked turbidity in the system with carp biomass in a simulation model of the aquatic community in the ORWRP. Results of their model predicted a steadystate fish community in the wetlands dominated by carp. Significant carp and muskrat activity in the wetlands suggests that bioturbation indeed caused resuspension of the sediments, and therefore could have influenced the observed depositional patterns.

Effect of Water Depth 


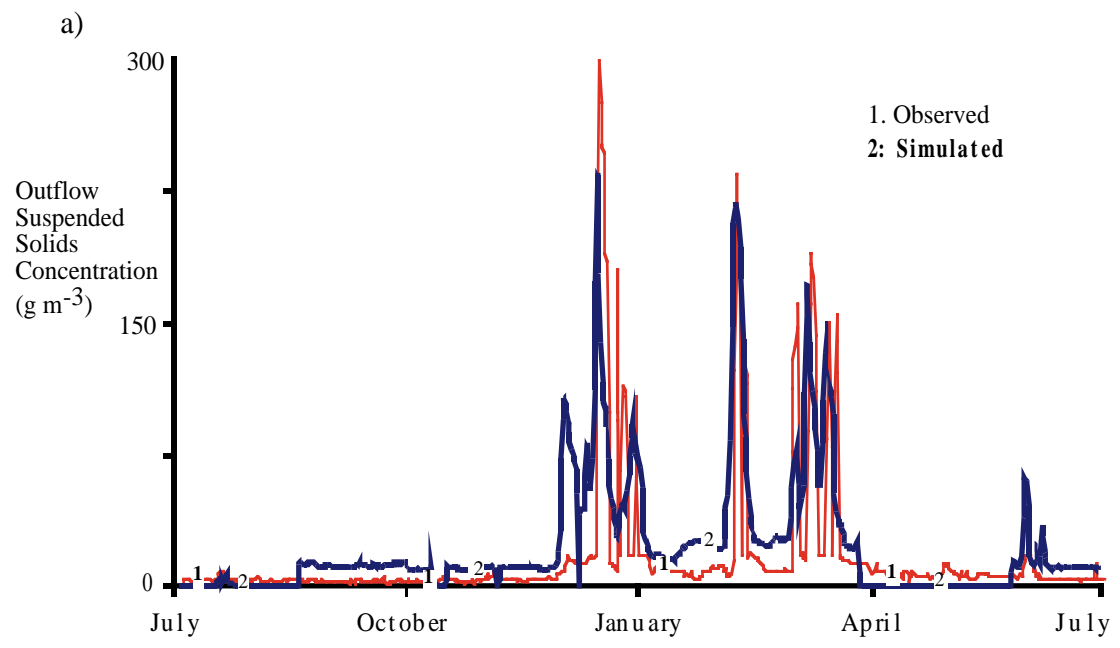

b)

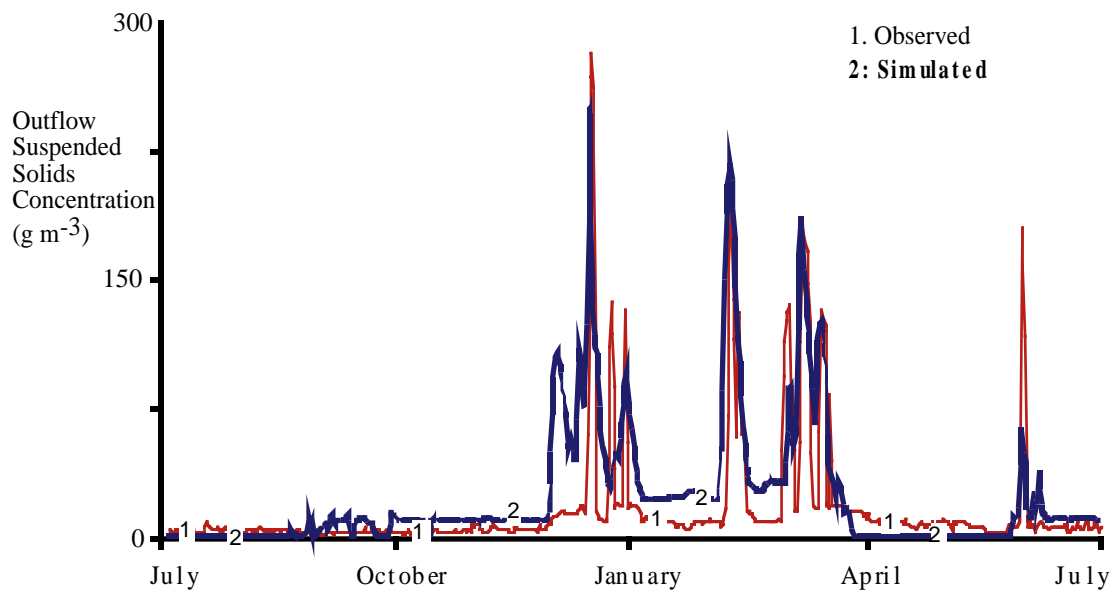

Figure 10. Comparison of observed outflow suspended solids concentrations with simulated outflow concentrations for a) Wetland 1 and b) Wetland 2 when the sediment resuspension rate is doubled.

Most of the shallow plots in this study were moderately to densely vegetated with emergent macrophytes, whereas none of the deepwater plots contained emergent vegetation. Therefore deep, open water areas had higher sedimentation rates than shallow, vegetated areas in the two wetlands. This result contradicts the findings of studies that have shown vegetated areas to enhance sedimentation in wetlands (Carpenter and Lodge, 1986; Dieter, 1990). However, the result is consistent with studies of other freshwater wetlands that found higher sedimentation rates in open water areas (Brueske and Barrett, 1994; Fennessy et al., 1994; Meeker, 1996). Fennessy et al. (1994) attributed the higher rates to preferential flow through open water areas and to greater insulation from resuspension. Preferential flow likely occurs in the two experimental wetlands at the ORWRP as dense macrophyte growth covers a majority of the shallow portion of each basin, leaving a relatively unobstructed flow path in the deepwater areas in the middle of each basin. Deepwater areas of each wetland may also protect the sediments from the effects of wind-induced resuspension, although much of the carp activity that was observed in the two wetlands was concentrated in the deepwater pools. Increased bioturbation from carp in deepwater areas may negate the winddampening effect.

\section{Comparison with other Sedimentation Studies}

Sedimentation rates measured in this study were much higher than those found in most studies of other wetland systems. Most reported wetland sedimentation rates vary between 0.5 and $1.0 \mathrm{~cm} \mathrm{yr}^{-1}$ (Table 6). Johnston (1991) reported an overall average sedimentation rate of $0.69 \mathrm{~cm}$ $\mathrm{yr}^{-1}$, or $1680 \mathrm{~g} \mathrm{~m}^{-2} \mathrm{yr}^{-1}$, in a review of several wetland sedimentation studies. Average sediment accretion rates measured in this study are approximately seven times higher, and average mass accumulation rates are 22 times higher than the average values reported by Johnston (1991). Many studies have reported much lower accretion rates. Sedimentation rates between 0.10 and $0.28 \mathrm{~cm} \mathrm{yr}^{-1}$ have been reported for forested floodplain wetlands in Arkansas and Tennessee (Hupp and Morris, 1990; Hupp and Blazemore, 1993). Sedimentation rates as low as 0.08 to $0.12 \mathrm{~cm} \mathrm{yr}^{-1}$ have been measured in tidal marshes (Conner 
a)

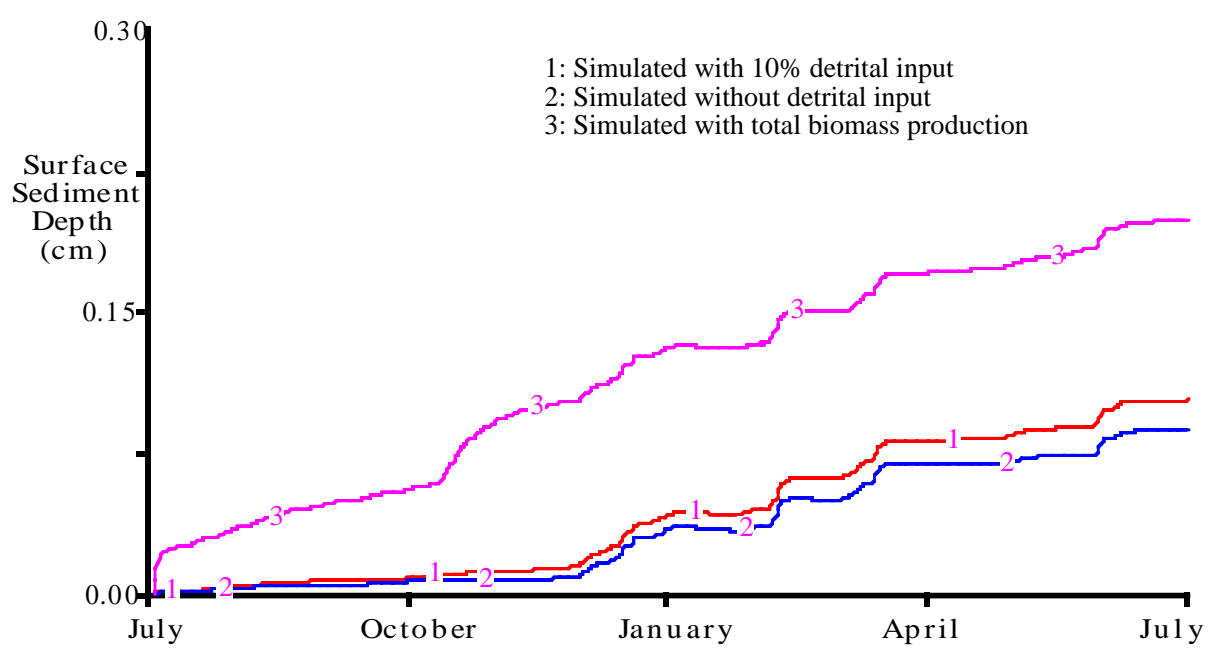

b)

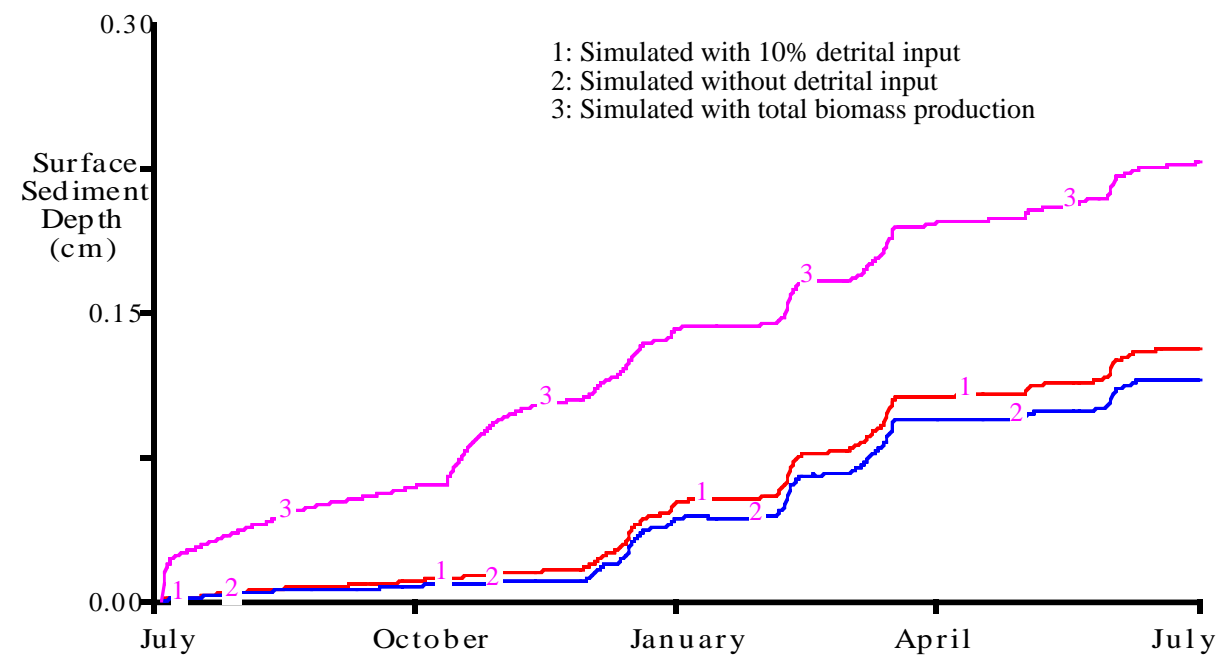

Figure 11. Comparison of surface sediment accumulation for a) Wetland 1 and b) Wetland 2 under different simulations of detrital input to surface sediments: 1) 10\% detrital input; 2) no detrital input; and 3) total system biomass production input.

and Day, 1991; Cahoon, 1994; Cahoon et al., 1996b).

Very few studies have reported sedimentation rates even close to those measured in this study. Knaus and Van Gent (1989) found an average sedimentation rate of $2.97 \mathrm{~cm} \mathrm{yr}^{-}$ ${ }^{1}$ for a freshwater marsh in Louisiana. Other coastal studies have measured isolated instances where sedimentation rates were as high as $8 \mathrm{~cm} \mathrm{yr}^{-1}$ (Reed, 1992; Cahoon et al., 1996b). Brueske and Barrett (1994) measured average sediment accumulation rates between 16.3 and $33.4 \mathrm{~cm} \mathrm{yr}^{-1}$ in a Illinois freshwater restored marsh, but pointed out that their values were collected on a limited spatial and temporal scale and most likely overestimated sedimentation for the system. In fact, another study of the same wetland estimated an annual accretion rate of only 0.5 to $1.0 \mathrm{~cm} \mathrm{yr}^{-1}$ (Fennessy et al., 1994).

\section{Comparison with Model Outcome and}

\section{Sediment Budget}

The model and sediment budget showed that far fewer sediments entered the wetland through the inflow than could account for the high average mass sediment accumulation measured in the core samples. The sediment budget estimated an average accumulation rate of $950 \mathrm{~g} \mathrm{~m}^{-}$ ${ }^{2} \mathrm{yr}^{-1}$ for Wetland 1 and $1025 \mathrm{~g} \mathrm{~m}^{-2} \mathrm{yr}^{-1}$ for Wetland 2 . These results are comparable to those reported in other studies (Table 6). For instance, Reed (1992) found average sediment accumulation rates ranging from 1000 to $2789 \mathrm{~g} \mathrm{~m}^{-2} \mathrm{yr}^{-1}$ in fresh and saltwater marshes in coastal Louisiana. The rate estimated from the sediment flux calculation is also close to the $1680 \mathrm{~g} \mathrm{~m}^{-2} \mathrm{yr}^{-1}$ average for several studies reviewed by Johnston (1991).

Mass accumulation data from the core samples were approximately 35 times (Figure 12) higher than the 
Table 6. Summary of sedimentation rates found in different wetland systems.

\begin{tabular}{|c|c|c|c|c|}
\hline Study Location & Method of Measurement & \multicolumn{2}{|c|}{$\begin{array}{l}\text { Sedimentation Rate } \\
\left.(\mathrm{cm} \mathrm{yr})^{-1}\right) \quad\left(\mathrm{g} \mathrm{m}^{-2} \mathrm{yr}^{-1}\right)\end{array}$} & Source \\
\hline $\begin{array}{l}\text { Average } \\
\text { many wetland } \\
\text { systems }\end{array}$ & varied & 0.69 & 1,680 & Johnston, 1991 \\
\hline \multicolumn{5}{|l|}{ Tidal Wetlands } \\
\hline California & horizon marker (feldspar) & $0.1-8.5$ & 7,300 & Cahoon et al., 1996b \\
\hline Maine & $\begin{array}{l}\text { horizon marker (glitter) } \\
\text { horizon marker (brick dust) }\end{array}$ & $\begin{array}{l}0.2-0.7 \\
0-1.3\end{array}$ & & $\begin{array}{l}\text { Harrison and Bloom, } 1977 \\
\text { Wood et al., } 1989\end{array}$ \\
\hline $\begin{array}{l}\text { Delaware River, } \\
\text { Pennsylvania }\end{array}$ & ${ }^{137} \mathrm{Cs},{ }^{210} \mathrm{~Pb}$ & 0.97 & 1,790 & Orson et al., 1990 \\
\hline Louisiana & $\begin{array}{l}{ }^{137} \mathrm{Cs},{ }^{210} \mathrm{~Pb} \\
\text { horizon marker (feldspar) } \\
\text { horizon marker } \\
\text { (rare earth elements) }\end{array}$ & $\begin{array}{l}0.47-0.90 \\
0.60-0.99 \\
0.84-2.97\end{array}$ & & $\begin{array}{l}\text { DeLaune et al., } 1989 \\
\text { Cahoon and Turner, } 1989 \\
\text { Knaus and Van Gent, } 1989\end{array}$ \\
\hline & horizon marker (feldspar) & $0.25-1.5$ & & Childers and Day, 1990 \\
\hline & horizon marker (feldspar) & $0.2-8.0$ & $1,000-19,000$ & Reed, 1992 \\
\hline & SET/feldspar & $0.38-2.6$ & & Cahoon et al., 1995 \\
\hline & horizon marker (feldspar) & $0.08-1.1$ & & Cahoon, 1994 \\
\hline & horizon marker (feldspar) & $0.12-4.4$ & & Conner and Day, 1991 \\
\hline & ${ }^{137} \mathrm{Cs},{ }^{210} \mathrm{~Pb}$ & $0.22-2.4$ & & Roman et al., 1997 \\
\hline $\begin{array}{l}\text { Mangroves } \\
\text { Gulf of Mexico }\end{array}$ & ${ }^{137} \mathrm{Cs}$ & $0.18-0.89$ & $374-5,308$ & Callaway et al., 1997 \\
\hline UK & $\begin{array}{l}\text { horizon marker (sand) } \\
\text { horizon marker (sand) }\end{array}$ & $\begin{array}{l}0.19-0.8 \\
0.39\end{array}$ & & $\begin{array}{l}\text { Stoddart et al., } 1989 \\
\text { French and Spencer, } 1993\end{array}$ \\
\hline Non-tidal Wetlands & & & & \\
\hline $\begin{array}{l}\text { Coastal } \\
1984 \\
\text { Great Lakes, } \\
\text { Michigan }\end{array}$ & ${ }^{137} \mathrm{Cs},{ }^{210} \mathrm{~Pb}$ & $0.05-0.9$ & $720-1,460$ & Kadlec and Robbins, \\
\hline $\begin{array}{l}\text { Coastal } \\
\text { Great Lakes, } \\
\text { Wisconsin }\end{array}$ & sediment traps & & $3,600-19,000$ & Meeker, 1996 \\
\hline Restored Marsh (IL) & $\begin{array}{l}\text { sediment traps } \\
\text { sediment traps }\end{array}$ & 16.3-33.4 & $\begin{array}{l}5,900-12,800 \\
2.1 \times 10^{5}-4.3 \times 10^{5}\end{array}$ & $\begin{array}{l}\text { Fennessy, et al., } 1994 \\
\text { Brueske and Barrett, } 1994\end{array}$ \\
\hline Forested Floodplain & dendrogeomorphic & $0.10-0.25$ & & Hupp and Morris, 1990 \\
\hline Arkansas & dendrogeomorphic & $0.24-0.28$ & & Hupp and Blazemore, 1993 \\
\hline Forested Floodplain & $\begin{array}{l}\text { varied } \\
\text { sediment plates }\end{array}$ & $0.01-1.96$ & $\begin{array}{l}14-1300 \\
3,540\end{array}$ & $\begin{array}{l}\text { Kleiss, } 1996 \\
\text { Mitsch et al., } 1979\end{array}$ \\
\hline (IL) & sediment traps & 0.8 & 5,621 & Mitsch et al., 1977 \\
\hline Created Marsh $(\mathrm{OH})$ & $\begin{array}{l}\text { horizon markers } \\
\text { (feldspar, glitter, sand) } \\
\text { mass balance }\end{array}$ & $1.71-9.23$ & $950-1,024$ & this study \\
\hline
\end{tabular}

accumulation rates predicted by the sediment flux calculation in both wetlands. These values were calculated using the assumption that the majority of the organic matter in the sediment originated from autochthonous production and therefore the OM fraction was subtracted from core sample mass accumulation rates. It is probable that some organic matter content was imported in inflow sediments, so the difference between core sample mass accumulation and the sediment flux calculation are likely to be somewhat higher.
Even if all biomass production became incorporated in the sediments, the model predicted that sedimentation rates would remain below $0.25 \mathrm{~cm} \mathrm{yr}^{-1}$. The model and the sediment budget therefore demonstrate that the observed sedimentation rate cannot be accounted for by sediments transported in the pumped inflow or by detrital production within the system The discrepancies between the model and sediment budget and the horizon marker results raise several interesting questions about the sedimentary processes 
occurring within the wetlands. Comparison of the model predictions and sediment budget with the observed sedimentation rate suggests that other sources of sediment inflow, such as overland flow during flood events, could have entered the wetlands. However, this explanation is unlikely as only one minor flood event occurred during the study period, which caused low flow into only Wetland 1 (Wang et al., 1998). Sediments may also have entered the wetlands from slope erosion of the basin edges. However, contribution from slope erosion was probably not significant, as there is a small swale around Wetland 1 to prevent erosion into the basin and only minor erosion was observed on the around the edges of both basins during the study period.

Erosion and resuspension of the existing sediment surface may also have contributed to the observed sedimentation rate. Resuspension of surface sediments through bioturbation has already been cited as contributing to the observed spatial pattern of sedimentation in the two wetlands. That only $53 \%$ of the cores successfully retrieved a visible marker layer (or 78\%, discounting clay markers which were never retrieved) also suggests that erosion may be an important factor in the observed sedimentation rates. Studies that have successfully used horizon markers to measure sedimentation have commonly had $91-100 \%$ retrieval success (French and Spencer, 1993; Cahoon et al., 1995). One of the major disadvantages to the horizon marker technique is that it can only account for resuspension of the sediments to the point where the artificial marker layer was placed on the substrate surface. Any further resuspension erodes the marker layer and destroys the reference point. When cores are retrieved without a visible marker, the cores do not provide a measurement of how much erosion took place, and in fact cannot even be counted as zero sedimentation because the exact timing and reason for the loss of the marker cannot be determined. As Cahoon et al (1995) point out, horizon markers are inherently biased toward measuring accretion rates while excluding eroded surfaces because those markers are lost. Therefore in systems where erosion and subsequent sedimentation plays a dominant role, horizon markers overestimate the actual sediment accretion rate.

Under the assumption that all markers which were not retrieved (47\%) were lost as a result of erosion, and that the erosion therefore contributed to almost half of the sedimentation rate, the sedimentation rate (corrected for

a)

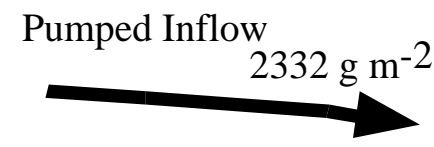

Outflow

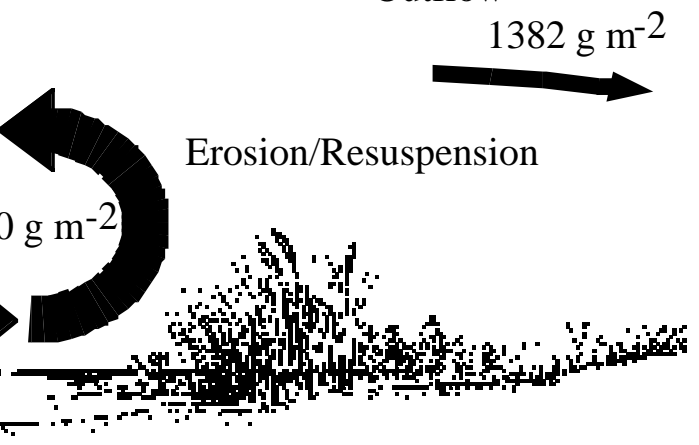

b)

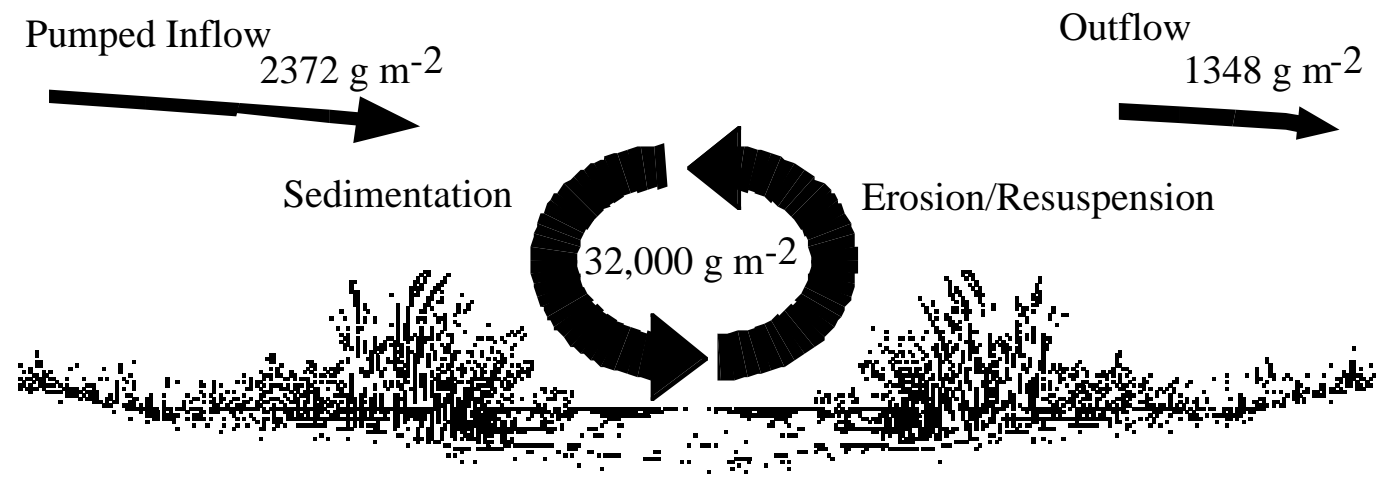

Figure 12. Annual sediment budget and mass accumulation in a) Wetland 1 and b) Wetland 2 showing the differences in sedimentation between the sediment budget and horizon marker study. 
erosion) for the wetlands would be approximately $2.5 \mathrm{~cm}$ $\mathrm{yr}^{-1}$. Although this estimate is much closer to values reported for other wetlands (Table 6), it still does not agree with the values of 0.11 to $0.25 \mathrm{cmyr}^{-1}$ predicted by the model and sediment budget. Regardless, the $2.5 \mathrm{~cm} \mathrm{yr}^{-1}$ estimation cannot be considered valid because not all of the markers were absolutely lost through erosion. Sometimes loss of the marker may have occurred when the marker floated away (witnessed in some areas with glitter when pumping resumed after marker installation) or if the marker was not laid down in a thick enough layer to be distinct. No distinguishable clay marker layers were retrieved indicating that either the marker color and texture blended with the clayey substrate or that the marker material dissolved in the water column.

The sediment budget indicated a sediment retention efficiency of $40.7 \%$ for Wetland 1 and $43.1 \%$ for Wetland 2. Sediment removal efficiencies predicted by the simulations for the experimental wetlands ranged between 27 and $68.6 \%$. The simulation which included a variable sediment settling velocity predicted a sediment retention which was only $5.5 \%$ lower than was observed in Wetland 1 and only $2.1 \%$ lower than was observed in Wetland 2. These values are much lower than the 76-99\% sediment retention that was found by Hey et al. (1994b) for a similar experimental wetland system in Illinois. Low removal efficiency of the wetland could result from biological activity, including carp and muskrats, within the basin that causes resuspension of the surface sediments or erosion of deeper sediments. Low sediment removal efficiencies could also result from the shorter hydrologic retention times that occurred for the two wetlands during 1997 (Mitsch and Montgomery, 1998). The detention time for the system studied by Hey et al. (1994a) averaged 11 days, while hydrologic retention in the wetlands at the ORWRP averaged only 2.1 days for the study period. The low hydrologic retention of the wetlands most likely accounted for the low sediment retention observed during this study. The sediment retention efficiency of the wetlands could therefore be improved if the hydrologic retention time was increased.

Ulbrich et al. (1997) found that hydrologic load can also influence the spatial distribution of sediments within a wetland. The authors' spatial sedimentation model showed that wetlands with lower retention times had a more even spatial distribution of sediments throughout the entire basin. Conversely, wetlands with high hydrologic retention tended to have concentrated sediment deposition near the inflow. These results may further explain the variability in sediment distribution observed in the experimental wetlands in this study. The low retention time may have caused sedimentation to occur more evenly throughout the wetlands.

One of the most interesting outcomes from the model was the distinct seasonal difference that was seen in sediment dynamics within the wetland system during the simulation time period. That the pattern of sediment retention was best described using a lower sediment settling velocity during the winter months suggests that the physical nature of the sediments may differ seasonally. Inflow sediments in the winter may have been composed of a larger proportion of organic materials, reflecting the transport of organic matter produced upstream during the previous growing season. Because of the lower bulk density of organic materials (Håkanson and Jansson, 1983; Mitsch and Gosselink, 1993), organic sediments may not have settled from the water column as rapidly. This possibility suggests the need for future analysis of the composition of inflow sediments to determine if a seasonal difference does exist. The seasonal differences may also be a result of other factors within the system that the model did not account for. For instance, the presence of live algae and macrophytes has been found to enhance sedimentation in wetlands and shallow lakes by reducing wind effects and water (Carpenter and Lodge, 1986; Dieter, 1990). The absence of these organisms during winter may have decreased the retention capacity of the shallow areas in the system. Future modelling efforts would benefit by expanding on the complexity of the primary productivity submodels and incorporating these possible vegetation influences.

\section{Effectiveness of Sedimentation Measurement Techniques}

The lack of physical explanation from within the wetlands for the differences between the sediment budget and horizon marker results may indicate a problem with using artificial soil horizon markers and the cryogenic coring technique to measure sedimentation within the wetlands at the ORWRP and in freshwater deep marshes in general.

Artificial soil horizon markers are biased against areas that undergo erosion (Cahoon et al., 1995). Results from this study indicate that erosion and resuspension may have played a significant role in the observed patterns of sediment deposition, and therefore contributed to the overestimation of sedimentation rates within the two wetlands. Since this wetland system is influenced by complex interactions between erosion and deposition, a sedimentation measurement technique which better accounts for erosion, such as the Sediment-Erosion Table, might prove more useful to describe sediment dynamics in the future (Boumans and Day, 1993; Childers et al., 1993; Cahoon et al., 1995; Day et al., 1998). The use of basic sediment traps could also improve sedimentation rate estimates in the two wetlands. However, since sediment traps prevent resuspension from occurring, their use would also overestimate sedimentation in the two wetlands (Brueske and Barrett, 1994; Fennessy et al., 1994).

Physical differences between the marker material and the wetland sediments may also have contributed to overestimation of the sedimentation rates within the two wetlands. Of the three marker materials, feldspar had a density that most closely resembled the low density of the wetland sediments. Feldspar in general gave the lowest estimation of wetland sedimentation, and sand and glitter tended to measure higher sedimentation rates. It is possible that the marker materials may have shifted down the sediment profile because of their differences in density and 
caused an overestimation of the sedimentation rate (Harrison and Bloom, 1977; Knaus and Van Gent, 1989). Support for this effect was most evident for the glitter marker as glitter was often vertically scattered throughout the sediment profile of the collected cores. Estimation of the sediment accumulation above the glitter marker had to be made by identifying the densest zone of glitter concentration within the core profile.

Cryogenic coring was specifically developed to sample loose, unconsolidated sediments and to minimize compaction during sampling (Knaus, 1986; Knaus and Cahoon, 1990; Cahoon et al., 1996a). The technique has been successfully used to sample wetland sediments in many studies, (Reed, 1992; Cahoon et al., 1995; Cahoon et al., 1996a) and was also very convenient for measuring accretion of the loose, flocculent sediments found in the wetlands at the ORWRP. Both the sediment-water interface and the horizon marker-sediment interface were easily distinguishable in the retrieved cores, allowing for a straightforward measurement of the accretion depth. More traditional coring techniques would not have permitted a readable, intact core to be retrieved from the substrate surface because of the unconsolidated, mucky nature of the sediments.

Even though the cores extracted with the cryocorer were generally intact and readable, some problems existed with this coring technique which probably greatly contributed to the overestimation of sedimentation rates in this study. Many of the extracted cores contained interwoven live macrophyte root segments or portions of buried algal mat material that could not be separated from the accumulated sediment for the accretion measurement. Although these materials should be considered in the measurement of sedimentation as autochthonous detrital production, much of the material seen in the cores was live plant tissue, or very recently senesced and thus occupied more volume in the core than detritus would. The overestimation in sedimentation rates caused by this issue should be relatively minor, especially when comparing the rates observed in this study with those reported by others. All coring techniques used in vegetated areas will produce cores which incorporate living biomass, and therefore observed rates across studies should remain comparable.

Any biases that live vegetation biomass contributed to measured sedimentation rates in this study should have been ameliorated when the accretion rates were converted to mass accumulation rates using the bulk density estimations. Bulk densities in this study were measured from cryogenic cores to minimize the effects of compaction (Knaus and Cahoon, 1990). Despite the fact that bulk densities were calculated based on cores collected with the cryogenic corer, it is likely that the bulk density estimations did not truly reflect the physical structure of the accumulated sediments. The larger core diameter needed to estimate bulk density (5 cm vs. $1 \mathrm{~cm}$ for regular cores) made it more difficult to freeze the entire core before extraction from the substrate surface. Some of the bulk density cores were therefore only partially frozen when they were initially extracted from the wetland unlike the completely frozen cores described in the method by Knaus and Cahoon (1990). The cores were subsequently frozen solid during transport to the lab in a cooler of dry ice, but because the bulk density cores were not completely frozen during removal from the substrate, disruption and compaction of the core sediments could have occurred.

Because most sedimentation studies have been conducted in tidal salt marshes (Reed, 1988; Cahoon and Turner, 1989; DeLaune et al., 1989; Stoddart et al., 1989; Wood et al., 1989; Conner and Day, 1991; French and Spencer, 1993; Cahoon, 1994; French et al., 1995; Cahoon et al., 1996b; Callaway et al., 1997; Reed et al., 1997; Roman et al., 1997) it is reasonable to assume that most sediment cores extracted in these studies were collected during periods of low tide when water depths were at or below the sediment surface. The sediments in these systems are probably much more consolidated at low tide than the soft, flocculent sediments in the deepwater basins at the ORWRP. The differences in the physical structure of the sediments between systems that experience prolonged inundation and systems with water levels at or below the sediment surface may explain why sediment accretion rates were so much higher in the ORWRP than those observed in other studies. One relatively easy solution to the problem of measuring sedimentation in the deepwater marshes at the ORWRP would be to collect cores during a drawdown when marsh surfaces are exposed. Unfortunately this method would require a complete drawdown of the entire basin, including the deep pools, which are usually left inundated as refuges for aquatic fauna during the drawdown. Sampling of the exposed marsh surface, however, may be the only way to produce better estimations of sedimentation rates for created freshwater marshes using the artificial soil horizon marker method and cryogenic coring technique.

\section{Implications for Created Wetlands}

The importance of water depth in influencing the rate and distribution of sedimentation within the wetlands in this study has implications for the design of other created wetland systems. The deepwater areas in the wetlands at the ORWRP effectively acted as retention ponds for sediment removal from the water column. Designing created wetlands with a large proportion of deepwater areas could therefore enhance their sediment removal function and lengthen the effective lifetime of the wetlands. Because of the intimate relationship between sediment and phosphorus retention, wetlands designed with more deepwater areas could also enhance phosphorus removal. Design criteria, however, must specifically address which wetland functions are desired. The creation of more deepwater areas necessitates a trade-off of other important wetland functions such as increases habitat diversity or enhanced nitrate retention in shallow, more densely vegetated areas.

Sedimentation studies can be useful for predicting the functional lifetime of created wetland systems. Data collected 
over a longer period of time than this study, however, are necessary to make reasonable predictions. Compaction of accumulated sediments is an important factor in the sediment dynamics of wetland systems and can only be analyzed with long-term data. In newly created wetlands, it is also important to consider the development of other ecosystem processes when predicting future sediment dynamics. For instance, as the vegetation community develops in newly created wetland systems, the sediment dynamics are likely to be affected.

\section{References}

Bouchard, V., and S. K. Harter. 1998. Wildlife observations in the two experimental basins at the Olentangy River Wetland Research Park in 1997. In: Mitsch, W.J., and V. Bouchard (eds.), Olentangy River Wetland Research Park at The Ohio State University, Annual Report 1997. School of Natural Resources, The Ohio State University, Columbus, OH. pp. 177-182.

Bouchard, V., W.J. Mitsch, and N. Wang. 1998. Plant diversity and community establishment after four growing seasons in the tweo experimental basins at the Olentangy River Wetland Research Park. In: Mitsch, W.J., and V. Bouchard (eds.), Olentangy River Wetland Research Park at The Ohio State University, Annual Report 1997. School of Natural Resources, The Ohio State University, Columbus, OH.pp. 51-70.

Boumans, R.M.J., and J.W. Day, Jr. 1993. High precision measurements of sediment elevation in shallow coastal areas using a sedimentation-erosion table. Estuaries 16: 375-380.

Breukelaar, A.W., E.H.R.R. Lammens, J.G.P. Klein Breteler, and I Tatrai. 1994. Effects of benthivorous bream (Abramis brama) and carp (Cyprinus carpio) on sediment resuspension and concentrations of nutrients and chlorphyll $a$. Freshwater Biology 32: 113-121.

Brueske, C.C., and G.W. Barrett. 1994. Effects of vegetation and hydrologic load on sedimentation patterns in experimental wetland ecosystems. Ecological Engineering 3: 429-447.

Cahoon, D.R. 1994. Recent accretion in two managed marsh impoundments in coastal Louisiana. Ecological Applications 4: 166-176.

Cahoon, D.R., and R.E. Turner. 1989. Accretion and canal impacts in a rapidly subsiding wetland II. Feldspar marker horizon technique. Estuaries 12: 260268.

Cahoon, D.R., D.J. Reed, and J.W. Day, Jr. 1995. Estimating shallow subsidence in microtidal salt marshes of the southeastern United States: Kaye and Barghoorn revisited. Marine Geology 128: 1-9.

Cahoon D.R., J.C. Lynch, and R.M. Knaus. 1996a.
Improved cryogenic coring device for sampling wetland soils. Journal of Sedimentary Research 66: 1025-1027.

Cahoon D.R., J.C. Lynch, and A.N. Powell. 1996b. Marsh vertical accretion in a southern California estuary, U.S.A. Estuarine, Coastal and Shelf Science 43: 19-32.

Callaway, J.C., R.D. DeLaune, and W.H. Patrick, Jr. 1997. Sediment accretion rates from four coastal wetlands along the Gulf of Mexico. Journal of Coastal Research 13: 181-191.

Carpenter, S.R. and D.M. Lodge. 1986. Effects of submersed macrophytes on ecosystem processes. Aquatic Botany 26: 341-370.

Childers, D.L. and J.W. Day Jr. 1990. Marsh-water column interactions in two Louisiana estuaries. I. Sediment dynamics. Estuaries 13: 393-403.

Childers, D.L., F.H. Sklar, B. Drake, and T. Jordan. 1993. Seasonal measurements of sediment elevation in three mid-Atlantic estuaries. Journal of Coastal Research 9: 986-1003.

Cline, J.M., T.L. East, and S.T. Threlkeld. 1994. Fish interactions with the sediment-water interface. Hydrobiologia 275/276: 301-311.

Cochran, M.W. 1998. Abundance and diversity of aquatic species in the experimental wetlands at the Olentangy River Wetland Research Park after four growing seasons. In: Mitsch, W.J., and V. Bouchard (eds.), Olentangy River Wetland Research Park at The Ohio State University, Annual Report 1997. School of Natural Resources, The Ohio State University, Columbus, OH. pp. 183-187.

Conner, W.H., and J.W. Day, Jr. 1991. Variations in vertical accretion in a Louisiana swamp. Journal of Coastal Research 7: 617-622.

Day, J.W., F. Scarton, A. Rismondo, and D. Are. 1998. Rapid deterioration of a salt marsh in Venice Lagoon, Italy. Journal of Coastal Research 14: 583-590.

DeLaune, R.D., J.H. Whitcomb, W.H. Patrick, Jr., J.H. Pardue, and S.R. Pezeshki. 1989. Accretion and canal impacts in a rapidly subsiding wetland I. Cs-137 and $\mathrm{Pb}-210$ techniques. Estuaries 12: 247-259.

Dieter, C.D. 1990. The importance of emergent vegetation in reducing sediment resuspension in wetlands. Journal of Freshwater Ecology 5: 467-473.

Fennessy, M.S., C.C. Brueske, and W.J. Mitsch. 1994. Sediment deposition patterns in restored freshwater wetlands using sediment traps. Ecological Engineering 3: 409-428.

Findlay, S., K. Howe, and H.K. Austin. 1990. Comparison of detritus dynamics in two tidal freshwater wetlands. Ecology 71: 288-295.

French, J.R., and T. Spencer. 1993. Dynamics of 
sedimentation in a tide-dominated backbarrier salt marsh, Norfolk, UK. Marine Geology 110: 315-331.

French, J.R., T. Spencer, A.L. Murray, and N.S. Arnold. 1995. Geostatistical analysis of sediment deposition in two small tidal wetlands, Norfolk, U.K. Journal of Coastal Research 11: 308-321.

Håkanson, L., and M. Jansson. 1983. Principles of Lake Sedimentology. Springer Verlag, Berlin, 316 p.

Hanson, M.A., and M.G. Butler. 1994. Responses of plankton, turbidity, and macrophytes to biomanipulation in a shallow prairie lake. Canadian Journal of Fisheries and Aquatic Sciences 51: 11801188.

Harrison, E.Z., and A.L. Bloom. 1977. Sedimentation rates on tidal salt marshes in Connecticut. Journal of Sedimentary Petrology 47: 1484-1490.

Harter, S.K. and W. J. Mitsch. 1998. Sediment accumulation and sediement measurement techniques in the Olentangy River experimental wetlands. In: Mitsch, W.J., and V. Bouchard (eds.), Olentangy River Wetland Research Park at The Ohio State University, Annual Report 1997. School of Natural Resources, The Ohio State University, Columbus, OH. pp. 135-144.

Hey, D.L., K.R. Barrett, and C. Biegen. 1994a. The hydrology of four experimental constructed marshes. Ecological Engineering 3: 319-344.

Hey, D.L., A.L. Kenimer, and K.R. Barrett. 1994b. Water quality improvement by four experimental wetlands. Ecological Engineering 3: 381-397.

Hupp, C.R., and E.E. Morris. 1990. A dendrogeomorphic approach to measurement of sedimentation in a forested wetland, Black Swamp, Arkansas. Wetlands 10: 107-124.

Hupp, C.R., and D.E. Blazemore. 1993. Temporal and spatial patterns of wetland sedimentation, West Tennessee. Journal of Hydrology 141: 179-196.

Johnston, C.A. 1991. Sediment and nutrient retention by freshwater wetlands: Effects on surface water quality. Critical Reviews in Environmental Control 21: 491565.

Jørgensen, S.E., S.R. Nielsen, and L.A. Jørgensen. 1991. Handbook of Ecological Parameters and Ecotoxicology. Elsevier, Amsterdam, 1263p.

Kadlec, R.H., and J.A. Robbins. 1984. Sedimentation and sediment accretion in Michigan coastal wetlands (USA). Chemical Geology 44: 119-150.

Kleiss, B.A. 1996. Sediment retention in a bottomland hardwood wetland in eastern Arkansas. Wetlands 16: 321-333.

Knaus, R.M. 1986. A cryogenic coring device for sampling loose, unconsolidated sediments near the water-sediment interface. Journal of Sedimentary
Petrology 56: 551-553.

Knaus, R.M., and D.L. Van Gent. 1989. Accretion and canal impacts in a rapidly subsiding wetland. III. A new soil horizon marker method for measuring recent accretion. Estuaries 12:269-283.

Knaus, R.M., and Cahoon, D.R. 1990. Improved crogenic coring device for measuring soil accretion and bulk density. Journal of Sedimentary Petrology 60: 622-623.

Meeker, J.E. 1996. Wild-rice and sedimentation processes in a Lake Superior coastal wetland. Wetlands 16: 219-231.

Meijer, M.L., M.W. de Haan, A.W. Breukelaar, andd H. Buiteveld. 1990. Is reduction of the benthivorous fish an important cause of high transparency following biomanipulation in shallow lakes? Hydrobiologia 200/201: 303-315.

Metzker, K.D., and W.J. Mitsch. 1997. Modelling selfdesign of the aquatic community in a newly created freshwater wetland. Ecological Modelling 100: 6186.

Mitsch, W.J., C.L. Dorge, and J.R. Wiemhoff. 1977. Forested wetlandss for water resource management in southern Illinois. Research Report 132, Water Resources Center, University of Illinois, ChampaignUrbana. 275 p.

Mitsch, W.J., W. Rust, A. Behnke, and L.Lai. 1979. Environmental observations of a riparian ecosystem during flood season. Research Report 142, Water Resources Center, University of Illinois, ChampaignUrbana. $64 \mathrm{p}$.

Mitsch, W.J. and B. C. Reeder. 1991. Modelling nutrient retention of a freshwater coastal wetland: estimating the role of primary productivity, sedimentation, resuspension and hydrology. Ecological Modelling 54: 151-187.

Mitsch, W.J. and J. G. Gosselink. 1993. Wetlands, $2^{\text {nd }}$ Ed. Van Nostrand Reinhold, New York, 722 p.

Mitsch, W.J., and V. Bouchard. 1998. Net primary productivity of macrophytes in experimental marshes. In: Mitsch, W.J., and V. Bouchard (eds.), Olentangy River Wetland Research Park at The Ohio State University, Annual Report 1997. School of Natural Resources, The Ohio State University, Columbus, OH. pp. 71-75.

Mitsch, W.J., and H. Montgomery. 1998. Water quality and nutrient removal patterns of created riparian wetlands: Fourth year results. In: Mitsch, W.J., and V. Bouchard (eds.), Olentangy River Wetland Research Park at The Ohio State University, Annual Report 1997. School of Natural Resources, The Ohio State University, Columbus, OH. pp. 89-95.

Mitsch, W.J., X. Wu, R.W. Nairn, P.E. Weihe, N. Wang, 
R. Deal, and C.E. Boucher. 1998. Creating and resoring wetlands: A whole-ecosystem experiment in self-design. Bioscience 48: 1019-1030.

Orson, R.A., R.L. Simpson, and R.E. Good. 1990. Rates of sediment accumulation in a tidal freshwater marsh. Journal of Sedimentary Petrology 60: 859-869.

Reed, D.J. 1988. Sediment dynamics and deposition in a retreating coastal salt marsh. Estuarine, Coastal, and Shelf Science 26: 67-79.

Reed, D.J. 1992. Effects of weirs on sediment deposition in Louisiana coastal marshes. Environmental Management 16: 55-65.

Reed, D.J., N. DeLuca, and A.L. Foote. 1997. Effect of hydrologic management on marsh surface sediment deposition in coastal Louisiana. Estuaries 20: 301311.

Roman, C.T., J.A. Peck, J.R. Allen, J.W. King, and P.G. Appleby. 1997. Accretion of a New England (U.S.A.) salt marsh in response to inlet migration, storms, and sea-level rise. Estuarine, Coastal, and Shelf Science 45: 717-727.

Stoddart, D.R., D.J. Reed, and J.R. French. 1989. Understanding salt-marsh accretion, Scolt Head Island, Norfolk, England. Estuaries 12: 228-236.

Svengsouk, L.J., R.K. Thiet, J.J. Gutrich, and W.J. Mitsch. 1997. Wildlife observations at the Olentangy River Wetland Research Park during the first three growing seasons. In: Mitsch, W.J. (ed.), The Olentangy River Wetland Research Park Annual Report 1996. School of Natural Resources, The Ohio State University, Columbus, OH. pp. 209-212.
Ulbrich, K., R. Marsula, F. Jeltsch, H. Hofmann, and C. Wissel. 1997. Modelling the ecological impact of contaminated river sediments on wetlands. Ecological Modelling 94: 221-230.

Wang, N., R.J.F. Bruins, W.J. Mitsch, and W.T. Acton. 1997. Water budgets of the two Olentangy River experimental wetlands, 1994-1996. In: Mitsch, W.J. (ed.), The Olentangy River Wetland Research Park Annual Report 1996. School of Natural Resources, The Ohio State University, Columbus, OH. pp. 55-84.

Wang, N., H. Montgomery, and W.J. Mitsch. 1998. Water budgets of the two Olentangy River experimental wetlands in 1997. In: Mitsch, W.J., and V. Bouchard, eds., Olentangy River Wetland Research Park at The Ohio State University, Annual Report 1997. School of Natural Resources, The Ohio State University, Columbus, OH. pp. 33-50.

Wu, X., and W.J. Mitsch. 1995. Biomass of algal mats, periphyton, and aquatic productivity in newly constructed wetlands. In: Mitsch, W.J., and X. Wu (eds.), Olentangy River Wetland Research Park at The Ohio State University, Annual Report 1994. School of Natural Resources, The Ohio State University, Columbus, OH. pp. 73-82.

Wilcox, T.P. and D.J. Hornbach. 1991. Macrobenthic community response to carp (Cyprinus carpio L.) foraging. Journal of Freshwater Ecology 6: 171-183.

Wood, M.E., J.T. Kelley, and D.F. Belknap. 1989. Patterns of sediment accumulation in the tidal marshes of Maine. Estuaries 12: 237-246. 